\title{
Higher Ethical Objective (Maqasid al-Shari'ah) Augmented Framework for Islamic Banks: Assessing Ethical Performance and Exploring Its Determinants
}

\author{
Arman Mergaliyev $^{1} \cdot$ Mehmet Asutay $^{1}$ (1) $\cdot$ Alija $^{\text {Avdukic }}{ }^{2} \cdot$ Yusuf Karbhari $^{3}$
}

Received: 29 July 2018 / Accepted: 22 October 2019 / Published online: 19 November 2019

(C) The Author(s) 2019

\begin{abstract}
This study utilises higher objectives postulated in Islamic moral economy or the maqasid al-Shari'ah theoretical framework's novel approach in evaluating the ethical, social, environmental and financial performance of Islamic banks. Maqasid al-Shari'ah is interpreted as achieving social good as a consequence in addition to well-being and, hence, it goes beyond traditional (voluntary) social responsibility. This study also explores the major determinants that affect maqasid performance as expressed through disclosure analysis. By expanding the traditional maqasid al-Shari'ah, we develop a comprehensive evaluation framework in the form of a maqasid index, which is subjected to a rigorous disclosure analysis. Furthermore, in identifying the main determinants of the maqasid disclosure performance, panel data analysis is used by including several key variables alongside political and socio-economic environment, ownership structures, and corporate and Shari'ah governance-related factors. The sample includes 33 full-fledged Islamic banks from 12 countries for the period of 2008-2016. The findings show that although during the nine-year period the disclosure of maqasid performance of the sampled Islamic banks has improved, this is still short of 'best practices'. Through panel data analysis, this study finds that the Muslim population indicator, CEO duality, Shari'ah governance, and leverage variables positively impact the disclosure of maqasid performance. However, the effect of GDP, financial development and human development index of the country, its political and civil rights, institutional ownership, and a higher share of independent directors have an overall negative impact on the maqasid performance. The findings reported in this study identify complex and multi-faceted relations between external market realities, corporate and Shari'ah governance mechanisms, and maqasid performance.
\end{abstract}

Keywords Islamic moral economy $\cdot$ Maqasid al-Shari'ah $\cdot$ Ethical performance $\cdot$ Islamic banks $\cdot$ Disclosure $\cdot$ Determinants

Mehmet Asutay

mehmet.asutay@durham.ac.uk

Arman Mergaliyev

mergaliev777@hotmail.com

Alija Avdukic

A.Avdukic@almcollege.ac.uk

Yusuf Karbhari

karbhari@cardiff.ac.uk

1 Durham Centre for Islamic Economics and Finance, Durham University Business School, Durham University, Durham, UK

2 Al-Maktoum College of Higher Education, Dundee, Scotland, UK

3 Cardiff Business School, Cardiff University, Cardiff, UK

\section{Introduction}

Islamic banking and financial institutions (IBFIs) emerged during the mid-1970s as 'commercial banks' to fulfil the religiously constructed financial needs of individual Muslims. They are considered value-oriented financial institutions shaped by the principles, morals and ethical norms of Islam. While the legal rulings in the form of Shari'ah injunctions determine the operational nature of IBFIs in the form of compliance, the normative nature of their operations is determined by the precepts of an Islamic Moral Economy (IME) (Asutay 2012). As a result, IBFIs are expected fulfil the normative expectations of IME as articulated by maqasid al-Shari'ah or 'objectives of the Shari'ah' (Asutay 2013; Asutay and Yilmaz 2018), which is defined as 'promoting human and social well-being' (Chapra 2000). 
The emergence of IBFIs was expected to motivate the socio-economic development of Muslim countries as institutions of IME by serving the financial needs of Muslim people in accordance with Islamic legal or Shari'ah principles, as IME emerged to construct a human-centred economic development paradigm. However, while IBFIs have been successful in mobilizing financial resources, they have been subjected to heavy criticism on the grounds that they are not fulfilling the 'substance' or the maqasid (objectives) of Shari'ah or 'human and social well-being' as identified by IME's transformational framework.

Despite the dynamic growth of the Islamic finance industry both in asset terms (1893.10 billion USD in 2016) and number (360) of IBs (The Banker 2017), the current practices of Islamic Banks (IBs) have been strongly criticised as not being truly 'Islamic' in their operations (El-Gamal 2006; Khan 2010; Asutay 2007a, b, 2012; Aksak and Asutay 2015). To compete with conventional financial institutions, IBFIs have oriented their strategies towards financial objectives rather than ethical and social objectives that require them to serve communities rather than contributing to financialization. The increasing financialization can be seen with the increased use of debt instruments as well as financing provided for financial markets and banks along with other activities which has financialisation consequences (on financialisation and debt orientation, see among others: Aggrawal and Yousef 2000; Nagaoka 2007; Asutay 2007a, b, 2012; Rudnyckyj 2014, 2018; Suzuki and Miah 2015; Farooq and Selim 2018; Yilmaz 2018). For example, in Malaysia, the use of organised tawarruq, which is a short-term liquidity solution within the Islamic sphere, has increased by 104 percent between 2014 and 2016 (Bank Nagara Malaysia 2016, pp. 90-91). The nature of organised tawarruq creates debt and increased further financialisation, and therefore is subjected to strong criticism, which was, therefore, ruled unlawful or Shari'ah non-compliant by the International Islamic Fiqh Academy but it is used liberally by the majority of Islamic banks due to market pressure, as indicated by the statistics in the case of Malaysia.

Contextually, in the IME-based operational axioms through which IBFIs can operate, they have adopted neoclassical assumptions and pragmatic attitudes and have therefore shifted away from the IME framework (Asutay 2007a). Consequently, IBs have 'failed' in achieving their social objectives as required by the IME foundations (Asutay 2012) and in the implementation of maqasid al-Shari'ah into their activities, in particular in social impact areas.

Considering that essential economic and social issues are still on the agenda of most of the Muslim countries worldwide, such as poverty reduction and enhancing levels of human development, IBFIs are expected to contribute to the ethical, social and economic spheres to realise the maqasid al-Shari'ah or social well-being. Therefore, it is crucial to assess the performance of Islamic banks (IBs) through the 'higher objectives' or the maqasid al-Shari'ah theoretical framework and identify factors which could positively or negatively influence IBs' ethical, social and economic performance. This will help to determine how IBs should be directed and operated in fulfilling the multidimensional objective of IBs and satisfy both the 'form' (Shari'ah legal rulings) as well as the 'substance' (social and moral filters) requirements of the Islamic worldview (Asutay 2012, pp. 98-99).

Since the theoretical framework of IME implies that IBs should conduct their financial operations in an ethical manner with social impact consequences, this study aims to fill the gap by going beyond the classical corporate social responsibility measures to assess their 'social and ethical responsibility'. In doing so, this study approaches the matter through the embedded notion of Islamic morality by developing a maqasid index to measure the endogenously constructed social or ethical behaviour of IBs. The evaluation of IBs' maqasid performance across 12 countries within the nine-year time frame (2008-2016) is studied to explore the determinants of maqasid performance consisting of the ethical, social and economic performance of the IBs. As a result, this research advances extant literature concerning the performance of IBs beyond financial performance and their determinants in relation to the normatively expressed objectives including their contribution to social development in their operating countries and communities.

This study also provides empirical evidence as to whether or not distinct corporate governance (CG) structures are affected by the maqasid al-Shari'ah's aspirational foundations within the IME framework and whether they perform better than other IFBIs, vis-à-vis CG, in areas of ethical, social and economic affairs. At the same time, the ethical, social and economic performance of IFBIs are also affected by external macro-factors and their environment, as examined in this study.

To the best of our knowledge, this is the first extended research to provide a cross-country empirical analysis of the factors which influence the performance of IBs in fulfilling the objectives within the maqasid al-Shari'ah theoretical framework through data gathered utilising disclosure analysis. Asutay and Hernangitas (2015) provided the initial descriptive study using a similar maqasid index, which this study applied as a basis for developing the current maqasid index utilised to generate the necessary data for assessing the maqasid performance of the sampled banks.

This study has, therefore, potential policy implications that can contribute to the work of national regulators, government authorities, and international standard setting organizations, such as the IFSB and AAOIFI, in constructing and developing appropriate mechanisms and best practices for the Islamic finance industry in improving IB performance 
to contribute to the development of communities and societies, which is essentialised by maqasid al-Shari'ah as the foundational objective function and methodology of IME. This study also contributes to the academic literature on Islamic finance by exploring factors which could influence the maqasid performance of IBs, and thus it discovers ways to enhance IBs by improving their maqasid performance with the idea that IBs should contribute to the socio-economic development of societies and countries in which they operate.

Overall, this study provides a novel approach and understanding of evaluating the social performance of IBs beyond merely replicating or mimicking CSR or corporate governance-related disclosure indices, as it develops an authentic evaluation method specific to IME as expressed through extended maqasid al-Shari'ah principles. It is hoped that such a method that is inherently Islamic in nature can prevail as a novel method in the literature.

The rest of the paper is organised as follows: a literature review on IME-based maqasid al-Shari'ah theoretical framework is presented in "Maqasid al-Shari'ah as the Ethical Framework for Islamic Banks" section. In "Islamic Banking and Finance and Its Ideal Identities" section, Islamic banking and finance and its ideal identities are discussed. "Survey of the Empirical Literature" section presents a survey of relevant empirical studies, while "Methodology" section provides a detailed description and procedure of research methodology including maqasid index construction and details of disclosure analysis, hypotheses formulation and method of analysis is employed. The empirical results relating to the maqasid performance of IBs with their determining factors are presented in "Empirical Results of Assessing the Maqasid Performance of Islamic Banks and Its Determinants" section. Finally, "Conclusion" section summarises the findings and provides the conclusion of the study which also offers a critical reflection on some of the more outstanding and pertinent issues.

\section{Maqasid al-Shari'ah as the Ethical Framework for Islamic Banks}

The ideal objective of IBs and their performance cannot be explored properly without discussing a theoretical framework of IME, which rationalises the existence of IBs. The IME-related debate emerged in the 1960s as a critique of both the capitalist and communist models of economic development, which ignores religious and ethical values, whereas, the primary objective of IME is to develop an economic system that would be human-centric and based on Islamic values and guided by the substantive justice of Islam (Asutay 2007a, p. 169). As a result of the knowledge creation process led by Muslim economists, the conceptual foundations of IME, its axioms, value system, operational dimensions and the behavioural norms of individual Muslims ('homoislamicus') have been developed based on the ontology and epistemology of Islam, namely, the Quran and Sunnah (Asutay 2007a, p. 171, 2007b, p. 5).

Asutay $(2007 b ; 2012 ; 2013)$ summarizes the foundational axioms of IME, which include the following:

Tawhid as complementarity and unitarity or God's unity and sovereignty, constitutes the nature of knowledge and its articulation implying that none of the stakeholders can have dominance over the others. This identifies that IME suggests an extended stakeholder governance system for IBs based on ihsan or equilibrium. For example, the prohibition of riba accordingly implies de-centring of capital and bringing capital to the same level with other stakeholers through the ihsani process.

Al-adl wa'l-ihsan refers to socio-economic justice and beneficence to establish equilibrium between the interests of all the stakeholders in an intergenerational and intragenerational manner, which defines the objective function of IBs. When justice cannot establish equal access, then ihsan through its balancing nature aims to overcome exclusion and fairness. Rububiyyah refers to a developmentalist path in the form of divine arrangements for nourishment, sustenance and guidance towards perfection, which identifies the operational objectives of IBs. It implies that all the stakeholders have a given path for development, and therefore, such development path must be sustained through the opportunity spaces.

Tazkiyah implies growth in harmony within tawhid's complementarity so that interests of all stakeholders can be served without harming any other, which implies a constraint on the operation of IBs.

Khilafah or vicegerency and accountability defines the role of humans in such an extended stakeholder governance; and

Maqasid al-Shari'ah, or the higher objectives of Islam, implies 'well-being' indicating that whatever action is taken and whatever is done should be in line with the well-being all of the stakeholders including human well-being.

Based on such foundational axioms, IME as a system, in a consequential manner, "refers to economic and sustainable development, social justice and social investingoriented principles" (Asutay 2012, p. 96). Therefore, it can be argued that an effective IME system requires that IBs conduct their activities in accordance with the principles of maqasid with an emphasis on social and economic dimensions by essentialising and adopting sustainable 
development practices along with fulfilling Islamic fiqhi or jurisprudential requirements.

Give that the foundational axioms are constructed by the maqasid al-Shari'ah methodological base of IME, which provides the legal and moral rationale and the theoretical framework within which economic activities should be performed (Asutay 2007b, p. 8; Asutay and Yilmaz 2018). Despite the existence of several different views of maqasid al-Shari'ah, a common treatment summarises it as the 'realization of well-being of all the stakeholders' (Asutay 2012, p. 96). The most common reference to maqasid in Islamic economics is given to the Ghazalian definition of maqasid, which is interpreted as 'human well-being' and articulated as "safeguarding their faith (dīn), their self (nafs), their intellect ( 'aql), their posterity (nasl), and their wealth (māl)" (Al Ghazali 1937; as cited in Chapra 2008, pp. 5-6) in constituting the IME axioms (Asutay and Yilmaz 2018). Chapra (2008) argues that while these five objectives could be considered primary, there are other necessary corollaries which can be found in the Qur'an, the Sunnah or in the writings of different Shari'ah scholars. Moreover, all primary objectives along with their corollaries are important, as "they are all interdependent and play the role of supporting each other" (Chapra 2008, p. 50). The Ghazalian definition of maqasid is, however, criticised for its individual-oriented objectives and its lack of social consideration (Auda 2007; Asutay and Yilmaz 2018). Among others, Siddiqi (2004), Auda (2007), Asutay (2007b) argue that maqasid should include wider issues such as justice and equity. Asutay and Yilmaz (2018), therefore, state that in order to develop into a comprehensive methodology of IME, maqasid al-Shari'ah should be taken away from the constraints of fiqh, while in terms of a tawhidi nature of knowledge must also be complemented by a moral base so that policy oriented consequences can be developed. In providing such a frame, Asutay and Yilmaz (2018) along with Siddiqi (2004) and Auda (2007) re-interpret maqasid to include a dynamic nature rather than 'safeguarding' or 'protection', and the non-limitation of objectives so that it will better conceptualize and handle contemporary issues beyond a narrow Ghazalian frame. Therefore, Asutay and Yilmaz (2018), among others, highlight that Ghazalian maqasid is not able to respond to the contemporary challenges in the operations of IBs in relation to IME's normative world. In responding to such concerns, this study refers to 'invigoration' rather than 'safeguarding' as part of Chapra's (2008) redefinition of maqasid.

Contrary to a Ghazalian view on the articulation of maqasid al-Shari'ah, with an attempt to respond to Siddiqi (2004), Auda (2007) and Asutay and Yilmaz's (2018) reinterpretation, Al-Najjar extended the maqasid based on four objectives and eight corollaries, as identified by Bedoui and Mansour (2014, p. 13), which is depicted in Table 1. However, Bedoui (2012, p. 5) points out that implementation of
Table 1 Najjar's concept of Maqasid al-Shariah. Source Adapted from Bedoui and Mansour (2014, pp. 567-568); modified version

Maqasid al-Shari'ah Corollaries

(i) Invigorating the value of human life
(a) Faith
(b) Human rights

(ii) Invigorating the human self
(a) Self
(b) Intellect

(iii) Invigorating society

(a) Posterity

(b) Social entity

(iv) Invigorating the physical environment

(a) Wealth

(b) Environment (ecology)

the corollary objectives is also required since the realization of the primary objectives may be onerous without them. Therefore, all eight maqasid corollaries should constitute the framework for a full assessment of IBs' social reference as an endogenously constructed frame based on Islamic ontology. In other words, through such a re-interpretation and extended maqasid as a dynamic construct beyond a safeguarding role, an embedded IME frame is constituted for the IBs to operate within (Asutay and Yilmaz 2018). In this, embeddedness refers to IBs operating within the social formation of an Islamic normative world rather than the mechanisms and instruments of a market system.

\section{Islamic Banking and Finance and Its Ideal Identities}

The creation of the first IBs in the 1970s represented the emergence of an alternative financial industry, which was expected to conduct its activities according to Shari'ah or Islamic legal requirements and the substantive morality promulgated by Islam. In relation to the IME framework, Asutay (2007a, p. 172) described Islamic finance as "an institutional aspect of Islamic economics which finances and regulates economic activity" to promote the economic development and well-being of all creatures, including human well-being through social justice. Therefore, IBs have emerged in response to expectations to operationalise IME.

Consequently, based on the IME theoretical framework, several ideals and principles have been advanced as key charecteristics of IBs. Among others, Chapra (1985, pp. 154-156) outlined several distinctive features of IBs, which include the abolition of interest, an orientation towards public interest, a universal or multi-purpose nature and not representing purely commercial or conventional banks but being catalysts for economic development through profit-and-loss 
sharing (PLS), and risk sharing principles with the objective of fulfilling social and economic justice, aiding the fair and impartial allocation of wealth and emancipating and empowering all the stakeholders.

In accordance with the IME's holistic approach, Asutay (2012) classified four characteristics of the values and norms of the ideal IB:

(i) As Islamic finance principles are derived from the ontology of Islam, the operations of IBs should not derive from riba (interest-based transactions), gharar (gambling), and speculative transactions, nor from the production of goods and services that violate Islamic norms (Ayub 2007) so that the interest of all the stakeholders should be positively considered by de-centring the hegemony of capital. Therefore, IBs in their operations are expected to endogenise the interests of all stakeholders beyond narrow shareholder maximisation objectives.

(ii) Based on Islamic values and norms, IB activities should be akin to ethical investing beyond just eliminating riba and gharar. At the same time, PLS-based financial contracts are encouraged in the form of mudharabah and musharakah or equity financing which will promote the development of entrepreneurial activities and greater stability in financial markets (Mirakhor and Zaidi 2007). Furthermore, the 'two-tier mudharabah model' was argued to be an ideal model of IBs as it "would fulfil the overall objectives of Shari'ah and achieve growth, equity and stability" (Ahmed 2011a, p. 73).

(iii) IB operations are based on asset-backed transactions as an articulation of their embedded financing proposition to link the monetary and real economy along with promoting stability, productivity and economic development (Iqbal and Molyneux 2005, p. 31).

(iv) As an IME aims to promote social justice, IBs are expected to endogenise socially oriented expectations with the aim to serve communities and not only 'markets' (Asutay 2012). Therefore, IBs are expected to serve the financial needs of all market segments, including small/micro-enterprises (SME) and the poor (Ahmed 2011b, p. 153). In addition, concepts such as waqf, zakah, sadaqah and qard hassan reflect the social dimensions of Islamic frameworks, and which is expected to also be presented in IBs' corporate social responsibility (CSR) practices (Platonova 2013).

According to the above ideal values within the IME framework beyond the financialised meaning of IBs, the ethical, social and economic dimensions are essentialised in IB operations as endogenous constructs rather than externally adopted principles. By definition, these correspond to maqasid al-Shari'ah consequences. Therefore, considering that the maqasid constitutes the main construct of IBs in articulating IME in their operations, it is important to assess the performance of IBs through the prism of these dimensions so that the proximity of their performance to the essentialised embedded nature can be identified beyond instrumentalised morality through exception-based morality essentialised by fiqhi forms as prevalent in the IB sector (Sencal and Asutay 2019).

\section{Survey of the Empirical Literature}

This section aims to present a review of the relevant empirical literature by clustering according to their objectives.

\section{Ethical, Social and Financial Performance of Islamic Banking and Financial Institutions}

In contrast to classical views on the performance assessment of financial institutions which are based mainly on financial and economic measures, a performance view in light of the maqasid al-Shari'ah is multidimensional and has a wider scope with the purpose of enhancing and sustaining human and societal well-being (Bedoui and Mansour 2014). However, Mohammed et al. (2008) argue that the failure of academic scholars to construct the multidimensional objectives for IBs has left no choice but to adopt the conventional unidimensional benchmarks of financial indicators to evaluate the performance of IBs. Therefore, performance assessment models and criteria are important to link IB activities with maqasid al-Shari'ah objectives in the context of IME.

To fill the gap in performance measurement-related theoretical frameworks, several studies have been conducted. For example, Hameed et al. (2004) developed the 'Islamicity Disclosure Index', which consists of Shari'ah compliance, $\mathrm{CG}$ and social/environmental indicators, and some financial ratios. In addition, Mohammed et al. (2008) constructed performance ratios for assessing the achievements of IBs in nine dimensions and ultimately covered three objectives including educating individuals, establishing justice and promoting welfare. Furthermore, Ngalim et al. (2015) has developed an 'Islamic Vision for Development' based indicators for the assessment of the maqasid al-Shari'ah of IBs in light of the five Ghazalian maqasid with supplementary corollaries. In addition to maqasid al-Shari'ah performance measurement frameworks, some studies analysed the ethical identity of IBs through CSR-based disclosure analysis based on annual reports, such as Haniffa and Hudaib (2007) and Belal et al. (2014). Moreover, Kasri and Ahmed (2015), in their attempt to develop operational indicators for a maqasidbased multidimensional poverty measure, included merely 21 items over five dimensions. In another attempt, Amir-UdDin (2014:25), using the fiqhi classification, "developed a Maqasid al-Shari' ah Index (MSI) corresponding to three levels of necessities, complementarities and embellishments", while this study is mainly related to expressed morality in terms of IME rather than 'rational-legal reasoning' provided 
by fiqh. In developing a structural model for human development, Mili (2014) utilises Ghazalian maqasid by adding a further dimension that is 'human well-being' resulting into six dimensions and 15 elements. In addition, with the objective of developing policy oriented maqasid index, Hasan and Ali (2018) constructs a maqasid al-Shari'ah deprivation perception index (MSDPI) for the Muslim countries utilising five dimensional Ghazalian maqasid index with 26 deprivation-related consequences to evidence the impact of the lack of such maqasid on human well-being. Despite the resemblances and utilising similar constructs, the methodological frameworks and measurements used in these attempts do not cover all the aspects of maqasid and they remain within the methodology and framework of CSRs applied to conventional banks. Therefore, a comprehensive and integrated maqasid index should be developed as attempted by this study, which covers an important gap in the literature.

In terms of the evaluation of actual ethical performance, several empirical studies provided evidence that while IBs achieve significant financial performance, they perform poorly in ethical and social dimensions targeted by IME. Asutay (2012) concluded that, based on empirical research, it can be claimed that there is a 'social failure' of IBs as a result of their shift from IME's equity-based objective to the neo-classical objective of efficiency.

In evidencing this, a number of benchmarks can be utilised. For example, in contrast to the ideal PLS or 'equity'-based financial contracts, IBs currently heavily utilize debt financing instruments, which has been referred to as the 'murabahah syndrome' (Yousef 2004). Among others, Nagaoka (2007) and Asutay (2012) demonstrate the dominance of debt-based Islamic instruments in the operations of Islamic banks, accounting for over $90 \%$ of their financing. As a result, more stakeholders perceive that the financing methods of IBs are the same as those of conventional banks, which provide debt financing deploying different mechanics.

Second, despite their impact on economic growth, the performance of IBs has not promoted the economic and social development of the communities they serve. Aksak and Asutay (2015) pointed out that the GCC countries, which themselves have a dynamic economic growth and a high level of wealth per capita in general, have failed in their human development. They showed that IBs have not helped in contributing to such objectives as part of their maqasid efforts. Therefore, it is claimed that IBs have not fulfilled the aspirations of IME in socio-economic developmentalist areas or embedding their operations within the maqasid frame.

Third, the IME paradigm provides a rationale for CSR as a social responsibility towards society and extends it through maqasid expectations. In contrast, according to several empirical studies, IBs have failed in their CSR practices. For example, among others, Sairally (2007), Haniffa and Hudaib (2007), Platonova (2013) and Belal et al. (2014) found that most IBs conduct only zakah distribution and other charitable activities without a systemic approach towards CSR. Thus, the social performance is a weak area in IB performance indicating dis-embeddedness in relation to the maqasid al-Shari'ah defined objectives.

Maqasid frame and IME identifies that IBs are expected to have the best practices and a comprehensive CG framework. According to Choudhury and Hoque (2006), tawhidi or shuratic models of CG have wider groups of stakeholders in comparison with Anglo-Saxon and even European models. Nevertheless, currently IBs have not developed distinct CG structures which continue to utilize shareholder-oriented models; therefore, Chapra and Ahmed (2002) identified that IBs do not protect the interests of all stakeholders. In relation to Shari'ah governance (SG), Hassan (2012) identified that there are no 'best practices' in SG, which could lead to the deterioration of Shari'ah dimensions in IB operations and therefore increase Shari'ah non-compliance risks.

Based on the stated empirical evidence, it can be argued IBs have not met the expectations of Islamic economists and Muslims in general, which is further substantiated by ElGamal (2006: xii) who stated that "Islamic finance has arguably failed to serve the objectives of Islamic law (maqasid al-Shari'ah)". Therefore, it is important to develop an empirical framework based on maqasid to test the observed shortcomings in the ethical and social performance of IBs in the context of maqasid al-Shari'ah by adopting an extended maqasid frame beyond the Ghazalian framework, as discussed above.

\section{Determinants of Islamic Banks' Performance and Disclosures}

Despite the dynamic growth of IBs in asset size and the complexity of their operations, few studies have addressed questions regarding the determinants of the financial, ethical, social and environmental performance of IBs, which is essentialised by the maqasid al-Shari'ah frame within the scope of Islamic finance, including both the institutional or socio-political context as well as organizational features. However, most of the empirical studies have explored only determinants of financial performance and the development of IBs. For example, Gazdar and Grassa (2015) identified the positive influence of macroeconomic factors, such as income per capita, economic openness and population, for Islamic finance in GCC countries while institutional factors were not considered relevant to the development of IBs. In another study, Mollah and Zaman (2015) investigated the positive influence of Shari'ah supervisory boards (SSB) on financial performance, and they found that corporate governance attributes, such as the board of directors' size, independence and its CEO, overall negatively impact IB financial 
performance. In focusing on ownership, Zouari and Taktak (2012) trace family and government ownership of IBs with higher financial performance while institutional and foreign shareholders do not have such influence on IBs.

In relation to the ethical, social and environmental dimensions, most studies have explored the determinants of the social and ethical reporting of IBs. Farook et al. (2011) report that the relative size of Muslim populations, the level of social and political freedom, the SSB, and the share of investment account holders (IAHs) to total assets positively influence CSR disclosure.

In addition, Yousef's (2004) cross-country analysis of 'murabahah syndrome' showed that legal institutions and political factors significantly influence the prevalence of debt-based instruments over equity-based ones in Islamic finance. As a result, Yousef (2004, p. 76) expects "that overall institutional environment will be a more important determinant of the evolution of financial structures in Muslim societies than ... rigid religious interpretations".

In conclusion, the IBs, as institutions of IME, are expected to emphasize their socio-economic role in society by enhancing their economic, social, ethical and environmental performance. However, as mentioned in the abovepresented studies, there is a gap in the current practices of IBs with regard to their ideal behaviour. Moreover, there is a lack of research in relation to the determinants of the economic, social, ethical and environmental performance of IBs. As a result, further empirical studies are required to determine the factors affecting the performance of IBs in light of maqasid al-Shari'ah, a task this study aims to fulfil in this paper.

\section{Methodology}

The empirical research in this paper is framed using a mix of qualitative and quantitative data based on the content analysis of annual reports for the generation of disclosure-related data for maqasid corollaries to identify the ethical performance of the sampled Islamic banks. In addition, secondary data were collected to identify the determining factors of disclosure performance through panel data analysis.

In conducting the content analysis for generating disclosure-related data, a crucial step is the design of specific categories or pre-determined keywords and their criteria into which content units of documents and texts can be attributed (Haniffa and Hudaib 2007). The categories and list of indicators for this research were designed mainly from the existing literature on the concept of the maqasid al-Shari'ah and its measurement of the performance of IBs, ethical and social reporting as well as 'the best practices' from Islamic and conventional finance.
The unit of analysis is the annual reports of the sampled banks, the contents of which are attributed to the maqasid dimensions. The generated disclosure data were converted into measurable categories.

In analysing the text through content analysis, the maqasid al-Shari'ah index was constructed and used as a benchmark. To mitigate any possible bias in scoring items during index calculation, an un-weighted approach was used to be consistent with previous studies, such as Belal et al. (2014) and Haniffa and Hudaib (2007). In the calculation of the maqasid al-Shari'ah index with all its sub-indices, as per Haniffa and Hudaib (2007), a mainly dichotomous approach was used in the sense that an item scored ' 1 ' if it was found in the annual report and ' 0 ' (zero) if it could not be found in the annual report.

Following estimations of the maqasid al-Shari'ah index and its dimensions as dependent variables, in the second part of the empirical analysis a linear regression model based on panel data was utilised to explore the impact of several independent variables of the disclosure performance.

\section{Construction of maqasid al-Shari'ah Index: Composition and List of Indicators for Disclosure Analysis}

For the purposes of designing the evaluative framework for the maqasid or ethical performance of the sampled IBs through disclosure analysis, Najjar's extended maqasid framework is implemented with four primary objectives and eight corollaries, as discussed in Bedoui and Mansour (2014). However, to link practice-related indicators of the economic, social, ethical and environmental performance of IBs with theoretically developed maqasid al-Shari'ah objectives and corollaries, Sekaran's (2000) method is utilized. Accordingly, 'concepts and notions' can be broken down into observable characteristics or 'dimensions', and, subsequently, they can be divided into measurable behaviours or 'elements.' In line with Mohammed et al. (2008), 'elements' are separated into a list of indicators of various performance ratios. Therefore, a comprehensive evaluative framework in relation to the maqasid al-Shari'ah framework is presented in Fig. 1, which is utilised in the empirical analysis.

Based on the existing literature, such as ethical performance by Belal et al. (2014), along with current 'best practices' in both Islamic and conventional finance (for example AAOIFI, IFSB and others), as well as macro and micro-level maqasid indicators developed by Mohamed (2018), a comprehensive list of benchmark performance indicators is constructed which are then traced to each 'element', to each 'dimension' and then ultimately to each 'concept' or maqasid objective. The index in its fullness is presented in "Appendix". It should be noted that not all performance indicators from the above-mentioned sources 
Fig. 1 The evaluation framework for IBs' Maqasid performance. Source: Adapted from Mohammed et al. (2008), Bedoui and Mansour (2014) and Asutay and Harningtyas (2015)

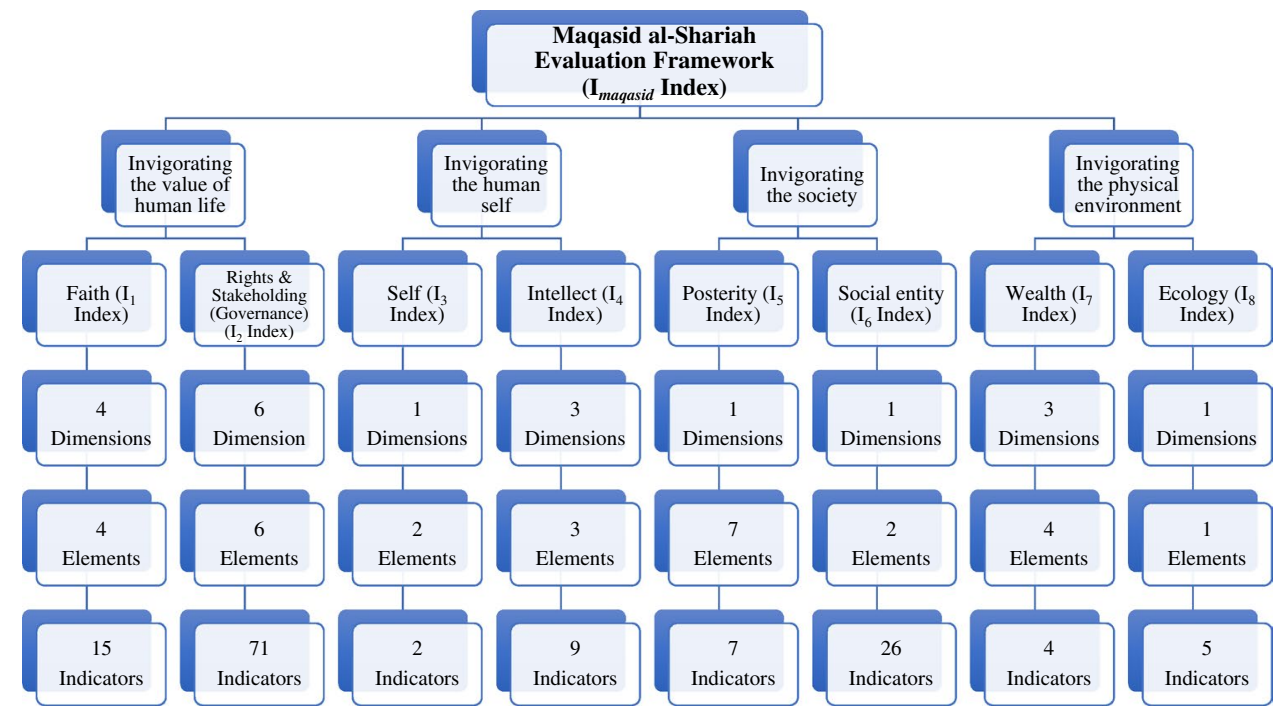

are utilised as only relevant indicators are included in the list. In quantifying, most indicators are scored based on a 'dichotomous approach': a score of ' 1 ' is given if the indicator is found in the annual report and ' 0 ' is given if not (Belal et al. 2014). In addition, some indicators are calculated based on ratios or other financial calculations.

To measure the overall maqasid performance of IBs and their separate performance in each primary objective, a maqasid al-Shariah index with sub-indices in each corollary is constructed. As mentioned above, the calculation of the index is based on an un-weighted approach and all indicators were weighted equally in each element's groups to control possible bias in the measurement of maqasid performance of the sampled IBs in line with previous studies such as Haniffa and Hudaib (2007). It should be noted that Antonio et al. (2012) used a weighted approach, which is not considered in this study due to its heavily subjective nature, as he constructed the weights through the interviews with the Shari'ah scholar. In addition, Moqbel (2014) in his research referred to the frequency of each of the MSI dimensions mentioned in the Qur'an is determining the weightage. However, tawhid axiom of the IME being complementarity within unitarity suggests that each dimension of MSI should be considered equally, as assigning different weights will essentialise certain dimensions on other by creating dominance. Tawhid by definition prevents any domination of any of the dimensions of MSI over the other, as this would be contrary to 'justice ( $a d l)$ ' and 'beneficence (ihsan)' axiom of IME too. Therefore, this paper refers to the unweighted method to fulfil the tawhidi expectation.

The calculation of maqasid al-Shari'ah sub-indices according to each corollary is completed through the following formula (Haniffa and Hudaib 2007):
$I_{i, t, c}=\frac{\sum_{t=1}^{n_{j}} X_{i, j}}{n_{j}}$

where $I_{i, t, c}$ : Maqasid al-Shari'ah sub-indices of ' $c$ ' corollaries of Najjar's maqasid of ' $i$ ' IB in year $t ; X_{i, j}$ : score of indicators of ' $i$ ' IBs in year $t$; $n_{j}$ : the overall number of indicators in ' $c$ ' corollaries.

Consequently, the calculation of the overall maqasid alShariah index is based on the following formula:

$I_{i, t}=\frac{\sum^{8} I_{i, t, c}}{8}$

where $I_{i, t}$ is the maqasid al-Shari'ah index of the performance of IBs $i$ in year $t$.

As there are eight corollaries in Najjar's maqasid framework, the sum of all sub-indices on each corollary was divided by eight.

\section{Hypotheses Development}

The research hypotheses in this study were developed based on the literature review, both on the determinants of performance and the disclosure practices of IBs as well as of conventional banks and corporations.

There are several factors which may have an impact on the economic, social, ethical and environmental performance of organizations. For example, Aguinis and Glavas (2012) highlight that companies conduct CSR activities due to institutional, organisational or individual factors. As for social reporting of IBs, Farook et al. (2011) analyse the influence of both country and IB-specific factors, in which two main groups of determinants are considered, including countryspecific factors such as socio-economic development and political context and IB-level specific factors. 
As part of the business environment, political and socioeconomic factors shape the environment in which every corporation operates, including IBs. Jones (1999) argues that a country's institutional arrangements in politics, law and economics along with the level of national development can enhance the social responsibility of organizations, neutrally sustain it or actively resist it. In line with this, Yousef (2004) traced the prevalence of 'murabahah syndrome' in civil law countries with weak institutions and non-democratic politics. Farook et al. (2011) outlined that within countries where political rights and civil liberties are limited, IBs could face lower social expectations and, thus, have incentives towards lower social disclosure. In contrast, in countries with a higher degree of freedom, IBs provide more disclosure to legitimize their existence. Therefore, it is expected that the higher a country's economic and human development, the higher the maqasid performance of IBs. Meanwhile, the higher the repression of political rights and civil liberties along with civil law system, the lower the maqasid performance of IBs. Hence, hypotheses 1, 2 and 3 are defined as follows:

$H_{l}$ : Human development positively affects the maqasid performance of IBs;

$\mathrm{H}_{2}$ : Political and civil repression negatively influences the maqasid performance of IBs;

$H_{3}$ : Civil law based legal systems negatively influence the maqasid performance of IBs.

Secondly, the size of the Muslim population in countries where IBs operate may influence their maqasid performance. Based on the concept of a 'relevant public' to whom the corporations are accountable, Newson and Deegan (2002) found evidence of a positive impact of the size of Muslim populations on the social reporting of IBs. Therefore, it is expected that the higher the Muslim population, the higher the maqasid performance of IBs, as Muslim communities could put pressure on IBs to perform better in the ethical, social and environmental dimensions of their activities. Hence hypothesis 4 is formulated as follows:

$H_{4}$ : The share of the Muslims population in a country's total population positively affects the maqasid performance of IBs.

As for the third factor, the ownership structure of IBs, Zouari and Taktak (2012) indicated that, according to the existing literature, the ownership structure and concentration are crucial factors that impact a company's financial performance and stability. However, they summarise that previous empirical studies reported mixed results on the relationship between ownership concentration and structure and performance. Nevertheless, their empirical study showed that family and government ownership of IBs positively influences their financial performance, whereas the same impact was not found in institutional and foreign shareholders. Therefore, it is expected that ownership structure either positively or negatively affects the maqasid performance of IBs, which is stated in hypothesis 5 as follows:

$H_{5}$ : There is a positive relationship between ownership structure and the maqasid performance of IBs.

The fourth factor is corporate governance related organizational structures and the features of the board of directors in IBs. Mollah and Zaman (2015) summarised that, according to the existing available literature related to all types of companies, there is mixed empirical evidence of the influence of governance mechanisms on a company's performance. Nevertheless, their study showed that a board of directors' size and independence are negatively affected by the financial performance of IBs. In contrast, Zeitoun (2013) identified that, within several corporate governance features of companies, only 'board independence' has a significantly positive effect on social performance. Thus, based on the above rationalisation, it is expected that the corporate governance structure may affect the maqasid performance of IBs, as identified in hypothesis 6:

$H_{6}$ : There is a positive relationship between corporate governance structures and the maqasid performance of IBs.

Finally, Shari'ah governance is one of the main features of IBs, ensuring that their products and operations are Shari'ah compliant, which are mainly presented by SSB features. Farook et al. (2011) proposed that SSBs could be a factor for CSR activities and social disclosures, and this was deduced from the SSBs' role as promoters of Shari'ah compliance and presenters of Islamic laws and principles. Therefore, it is expected that the better the Shari'ah governance, the higher the maqasid performance of IBs, as stated in hypothesis 7 :

$H_{7}$ : Shari'ah governance structures positively affect the maqasid performance of IBs.

After identifying the hypotheses, the following section explains the panel data model used to examine the factors impacting the disclosure performance in relation to maqasid al-Shari'ah.

\section{Panel Data Econometric Model}

In order to analyse and test the identified hypotheses in line with the stated aims, the following linear regression model was utilized:

$I_{i, t}=\alpha+\beta_{1} \operatorname{PSEC}_{i, t}+\beta_{2} O_{i, t}+\beta_{3} C G_{i, t}+\beta_{3} S S B_{i, t}+\beta_{4} C_{i, t}+\varepsilon_{i, t}$

where $I_{i, t}$ is the Maqasid al-Shari'ah Index and its eight corollaries in bank $i$ in year $t$; $P S E C_{i, t}$ is the vector of 
time-varying political and socio-economic context variables; $O_{i, t}$ is the vector of time-varying ownership structure variables; $C G_{i, t}$ is the vector of time-varying board of directors' variables; $S S B_{i, t}$ is the vector of time-varying SSB variables; $C_{i, t}$ is the vector of control variables; $\varepsilon_{i, t}$ is the white-noise error term.

In this paper, the dependent variable is the maqasid alShari'ah index (MSI), which is constructed by this study and calculated as explained above.

The independent variables in this paper are grouped into four main categories: (i) political and socio-economic context variables, (ii) corporate governance, (iii) SSB features related variables, and (iv) ownership structures of IBs along with economic and financial variables, as consistent with previous studies.

The political and socio-economic context variables include the 'Human Development Index"1 (HDI, as obtained from the UNDP website), 'political and civil repressions' (PCR, as presented using data from the Freedom in the World Index), and the 'Muslim population ratio' (MUSLIMRATIO, as a percentage of the Muslim population of a country using data from the CIA World Factbook). Three dummy variables relating to legal systems are 'common law' (COMLAW is marked ' 1 ' if the country uses a common law system and ' 0 ' if not), 'civil law' ('CIVLAW' is marked ' 1 ' if the country uses a civil law system and ' 0 ' if not) and 'Shari'ah law' ('SHARLAW', is marked ' 1 ' if the country uses an Islamic law system and ' 0 ' if not) by using data from the JuriGlobe database of Ottawa University. These variables are utilised in the existing literature, including by Jones (1999) and Farook et al. (2011).

\footnotetext{
${ }^{1}$ HDI is used in this study as an independent variable, which could be considered as a universal benchmark. While HDI has limitations in addition being the product of Eurocentric worldview, it remains one of the best proxies to reflect human development. The observed shortcomings in HDI has not stopped researchers to use it as a variable for human development as there is a vast literature in development field utilising HDI as a benchmark. Dar (2004), for example discusses the shortcomings of HDI and suggests that it should be made more humane. In a similar manner, Aydin (2017) proposes an alternative Islamic HDI and compares its results with the conventional HDI for ten Muslim countries. However, despite being a novel attempt, his research again uses benchmarks generated within conventional sphere. Similarly, Biggeria et al. (2018) propose a more 'sustainable' HDI by integrating the environment and freedom. Search, hence, will continue to develop a better measure for capturing the human development in an integrated manner, while HDI will be a subject for many other empirical researches such as Mishra and Nathan (2018) and Ngoo and Tey (2019). As the latter study uses HDI as a predictor of life satisfaction. Since this study utilises HDI only as an independent variable to capture the global debate, the philosophical nature of the discussion was avoided in the paper, as due to the ontological differences, a maqasid index is proposed and developed by this study to present a broader human well-being by integrating the other stakeholders' interests.
}

The 'corporate governance' variables consists of 'board independence' ('INED' as a percentage of non-executive directors in the board of directors), 'board pro-stakeholders directors' ('BPSD' as a percentage of board members, for example politicians, academic scholars and others who have not held any other positions in the other organizations in the same industry), 'board size' ('BS', as the number of members in the board of directors), 'CEO duality' ('CEOD' is marked as ' 1 ' if the CEO and chairman are the same person and ' 0 ' if otherwise) and 'investment account holders ratio' ('IAH' as a percentage of IAHs account deposits to equity). It should be noted that these variables have all been utilized in previous studies, such as Farook et al. (2011) and Mollah and Zaman (2015).

The SSB-related variables are presented by a few indicators as 'SSB composition' ('SSBC' is marked ' 1 ' if the SSB consists of more than 3 members and ' 0 ' if otherwise), 'SSB disclosure level' ('SSBD' represents the level of compliance of the SSB report with AAOIFI standards) and 'SSB control and monitoring abilities' ('SSBCM' represents the average marks of the three components including the number of meetings, cross-membership in other IBFs, and the SSBs' audit activities).

As regards to ownership structure, four dummy variables are included: 'government owned' (GOV), 'family owned' (FAM) 'institutional' (INST) and 'foreign ownership' (FORG). The respective variables are marked ' 1 ' if the IBs are owned by such owners. The same variables have been used in a previous study by Zouari and Taktak (2012), among others.

All the control variables are grouped into bank-specific control variables since several IB characteristics may positively or negatively influence maqasid performance in the form of social, economic and environmental performance according to previous studies. The control variables included in this paper are the 'IBs' size of assets' (SIZE), which is presented by a $\log$ of the total assets; 'the leverage level' (LEV), which is measured as the ratio of total debt to equity, and the 'date of incorporation' (AGE). All these variables have been utilized in several studies such as Beck et al. (2013), Zouari and Taktak (2012), and Rizkiningsih and Dewi (2015).

Furthermore, Gross Domestic Product' (GDP, as obtained from the World Bank) and 'Financial Development' (FD obtained from IMF) variables are included to capture the role of economic growth and financial development, respectively, on the maqasid performance.

Table 2 presents the independent and dependent variables and the data sources. 
Table 2 Variables and data sources (sample 2008-2016)

\begin{tabular}{|c|c|c|c|}
\hline Acronym & Definition of variables & Source & Years (available) \\
\hline$I_{\text {maqasid }}$ & Maqasid al-Shari'ah index & Eight corollaries & 2008-2016 \\
\hline$I_{1}$ & Faith index & Annual Reports & $2008-2016^{\mathrm{a}}$ \\
\hline$I_{2}$ & Rights and stakeholding index & Annual Reports & $2008-2016^{\mathrm{a}}$ \\
\hline$I_{3}$ & Self-index & Annual Reports & $2008-2016^{\mathrm{a}}$ \\
\hline$I_{4}$ & Intellect index & Annual Reports & $2008-2016^{\mathrm{a}}$ \\
\hline$I_{5}$ & Posterity index & Annual Reports & $2008-2016^{\mathrm{a}}$ \\
\hline$I_{6}$ & Social entity index & Annual Reports & $2008-2016^{\mathrm{a}}$ \\
\hline$I_{7}$ & Wealth index & Annual Reports & $2008-2016^{a}$ \\
\hline$I_{8}$ & Environment index & Annual Reports & $2008-2016^{\mathrm{a}}$ \\
\hline GDP & Gros Domestic Product (log form) & The World Bank & $1960-2018^{\mathrm{b}}$ \\
\hline FD & Financial Development & IMF website & $1980-2017^{b}$ \\
\hline HDI & Human Development Index & UNDP website & $1990-2018^{b}$ \\
\hline PCR & Political and civil repression & Freedom in the World Index & 2005-2018 \\
\hline MUSLIMRATIO & A percentage of Muslim ration in the country & CIA World Factbook & $2008-2016^{\mathrm{b}}$ \\
\hline COMLAW & A common law system & JuriGlobe database of Ottawa University & 2008-2016 \\
\hline CIVLAW & A civil law system & JuriGlobe database of Ottawa University & 2008-2016 \\
\hline SHARLAW & An Islamic law system & JuriGlobe database of Ottawa University & 2008-2016 \\
\hline INED & $\begin{array}{l}\text { Board independence as a percentage of non-executive directors } \\
\text { in the board of directors }\end{array}$ & Annual Reports & $2008-2016^{\mathrm{a}}$ \\
\hline BPSD & $\begin{array}{l}\text { Board pro-stakeholders' directors as a percentage of board } \\
\text { members }\end{array}$ & Annual Reports & $2008-2016^{\mathrm{a}}$ \\
\hline $\mathrm{BS}$ & Board size as the number of members in the board of directors & Annual Reports & $2008-2016^{\mathrm{a}}$ \\
\hline CEOD & CEO duality & Annual Reports & $2008-2016^{\mathrm{a}}$ \\
\hline IAH & Investment account holder's ratio & Annual Reports & $2008-2016^{\mathrm{a}}$ \\
\hline SSBC & SSB composition & Annual Reports & $2008-2016^{\mathrm{a}}$ \\
\hline SSBD & SSB disclosure level & Annual Reports & $2008-2016^{\mathrm{a}}$ \\
\hline SSBCM & SSB control and monitoring abilities & Annual Reports & $2008-2016^{\mathrm{a}}$ \\
\hline GOV & Government owned bank & Annual Reports & $2008-2016^{\mathrm{a}}$ \\
\hline FAM & Family owned bank & Annual Reports & $2008-2016^{\mathrm{a}}$ \\
\hline INST & Institutionally owned bank & Annual Reports & $2008-2016^{\mathrm{a}}$ \\
\hline FORG & Foreign ownership bank & Annual Reports & $2008-2016^{\mathrm{a}}$ \\
\hline SIZE & Islamic Banks' size of assets & Annual Reports & $2008-2016^{\mathrm{a}}$ \\
\hline LEV & $\begin{array}{l}\text { The leverage level which is measured as the ratio of total debt } \\
\text { to equity }\end{array}$ & Annual Reports & $2008-2016^{\mathrm{a}}$ \\
\hline AGE & The date of incorporation of bank & Annual Reports & $2008-2016^{\mathrm{a}}$ \\
\hline
\end{tabular}

${ }^{a}$ Differ from bank to bank; ${ }^{b}$ differ from country to country

\section{Generating Data Through Disclosure Analysis}

In order to test the hypotheses developed, the annual reports of 33 IBs from 12 countries over nine-year period covering 2008-2016 were utilised for disclosure analysis, with a total number of 297 annual reports. The sample selection was determined by the availability of the annual reports on the IBs' websites with a preference for large and well-established IBs in terms of assets in each country. The choice of selecting 12 countries was motivated by the necessity to cover a wider range of countries with IB presence along with the aim of capturing the impact of different socio-political, institutional and human development level contexts. The sample of IBs, with such characteristics as being listed or non-listed companies, their country of origin, as well as their total assets by the end of 2016, are presented in Table 3 . Since the data generation is based on disclosure index and analysis, expanding the sample was not possible due to a very large maqasid index with 139 items.

As for the bank-specific, economic and political economy variables, the Zawya, BankScope, IMF, the UNDP and World Bank databases were utilised. 
Table 3 Sampled Islamic banks. Source: BankScope Database

\begin{tabular}{|c|c|c|c|c|}
\hline No & Bank & Country & Listed/not listed & $\begin{array}{l}\text { Total assets } \\
\text { (USD) } 2016\end{array}$ \\
\hline 1 & Al-Rajhi & Saudi Arabia & Listed & 90,589 \\
\hline 2 & $\mathrm{KFH}$ & Kuwait & Listed & 53,893 \\
\hline 3 & DIB & UAE & Listed & 47,643 \\
\hline 4 & QIB & Qatar & Listed & 38,415 \\
\hline 5 & ADIB & UAE & Listed & 33,298 \\
\hline 6 & Alinma Bank & Saudi Arabia & Listed & 27,927 \\
\hline 7 & Masraf Al Rayan & Qatar & Listed & 25,145 \\
\hline 8 & Al Baraka & Bahrain & Listed & 23,425 \\
\hline 9 & Bank Rakyat & Malaysia & Unlisted & 22,117 \\
\hline 10 & Bank Al Jazira & Saudi Arabia & Listed & 17,685 \\
\hline 11 & Bank Islami MB & Malaysia & Unlisted & 12,411 \\
\hline 12 & Ahli United Bank Kuwait & Kuwait & Listed & 12,059 \\
\hline 13 & Al-Hilal & UAE & Unlisted & 11,824 \\
\hline 14 & QIIB & Qatar & Listed & 11,689 \\
\hline 15 & RHB Islamic Bank Berhad & Malaysia & Unlisted & 10,725 \\
\hline 16 & IBBL & Bangladesh & Listed & 10,138 \\
\hline 17 & BPM Berhad & Malaysia & Unlisted & 5987 \\
\hline 18 & Bank Syariah Mandiri & Indonesia & Unlisted & 5867 \\
\hline 19 & Jordan Islamic Bank & Jordan & Listed & 5773 \\
\hline 20 & Bank Muamalat & Malaysia & Unlisted & 5314 \\
\hline 21 & Al Salam Bank & Bahrain & Listed & 4471 \\
\hline 22 & KFH Bahrain & Bahrain & Unlisted & 4276 \\
\hline 23 & Meezan Bank & Pakistan & Listed & 4226 \\
\hline 24 & PT Bank Muamalat Indonesia & Indonesia & Unlisted & 4152 \\
\hline 25 & Export-Import Bank of Bangladesh & Bangladesh & Listed & 3699 \\
\hline 26 & Bahrain Islamic Bank & Bahrain & Listed & 2771 \\
\hline 27 & Faisal Islamic Bank (Sudan) & Sudan & Unlisted & 2378 \\
\hline 28 & PT Bank BRI Syariah & Indonesia & Unlisted & 2060 \\
\hline 29 & Al Rayan Bank Plc & UK & Delisted & 1766 \\
\hline 30 & BankIslami Pakistan Ltd & Pakistan & Listed & 1736 \\
\hline 31 & Safwa Islamic Bank & Jordan & Listed & 1295 \\
\hline 32 & Al Baraka Sudan & Sudan & Listed & 408 \\
\hline 33 & Al-Shamal Bank & Sudan & Listed & 340 \\
\hline
\end{tabular}

\section{Empirical Results of Assessing the Magasid Performance of Islamic Banks and Its Determinants}

This section presents the empirical results including the disclosure performance assessment, the descriptive statistical analysis of the evaluations of maqasid performance at the individual bank and country levels as well as results of the panel data econometric analysis to locate the determinants of disclosure. Finally, in ensuring the reliability of the empirical process, a robustness test was performed; this is also presented in this section.

\section{The Maqasid Performance of the Sampled IBs}

The first set of analyses in this section examines the maqasid performance of each of the sampled IBs, which is summarised in Table $4 .^{2}$ As can be seen, Safwa Islamic Bank (4.8488), Jordan Islamic Bank (2.473), Faisal Islamic Bank (Sudan) (1.8896) and PT Bank Syariah Mandiri (Indonesia) (1.8087), PT Bank BRI Syariah (Indonesia) (1.4398) are the

\footnotetext{
2 The full results of the evaluation of the IBs' performances for each component of the maqasid can be made available upon request as due to length issue they are not presented here. It should also be noted that since certain financial ratios have also been included as part of the MSI developed in this study, the scores are higher than 1; however, normally disclosure analysis scores should be maximum 1 .
} 


\begin{tabular}{|c|c|}
\hline Uే & 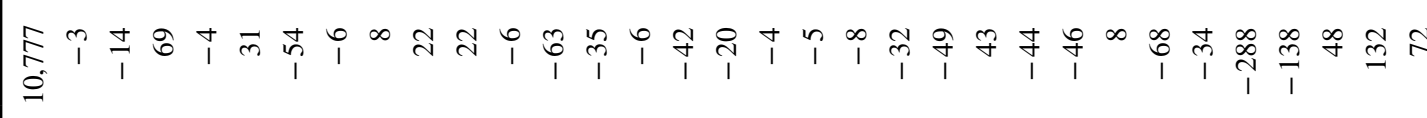 \\
\hline & 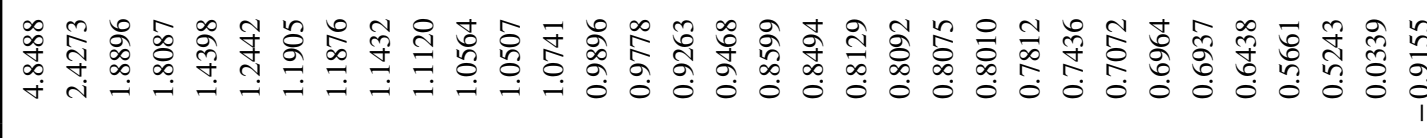 \\
\hline & 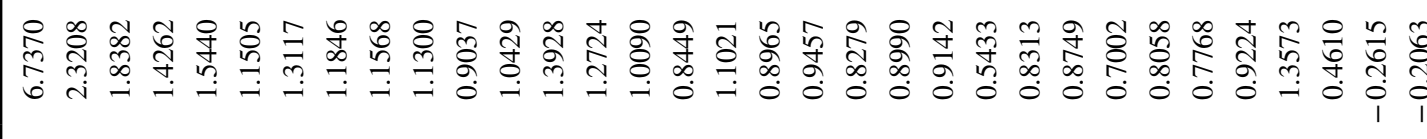 \\
\hline & 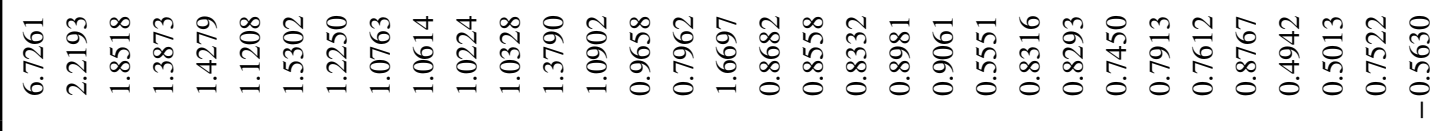 \\
\hline & 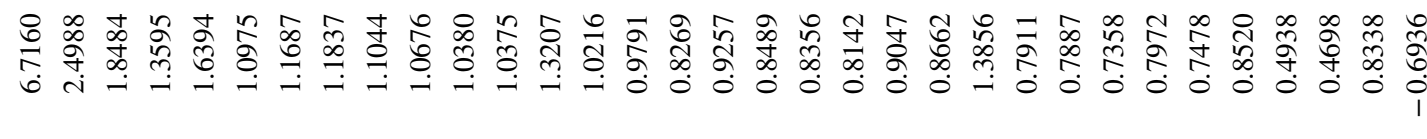 \\
\hline & 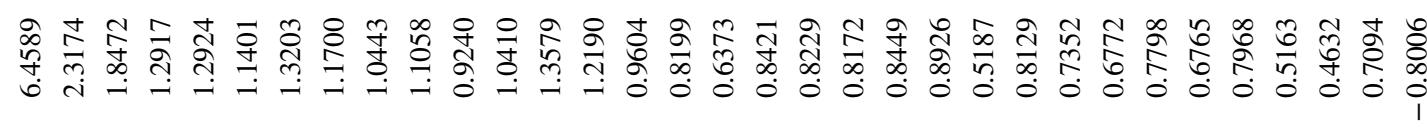 \\
\hline 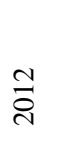 & 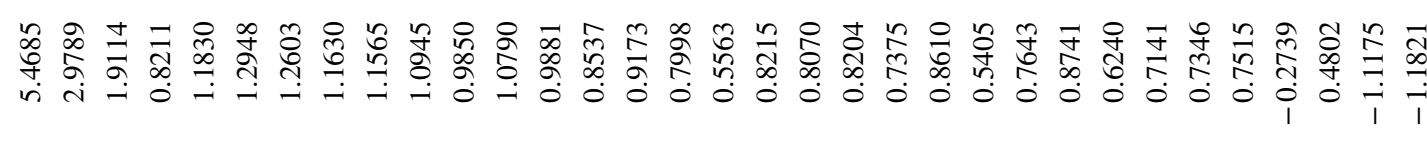 \\
\hline & 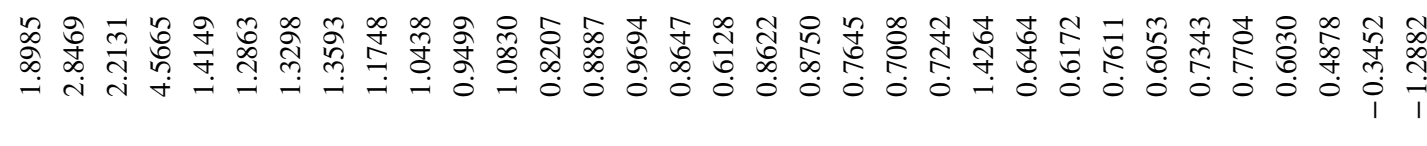 \\
\hline & 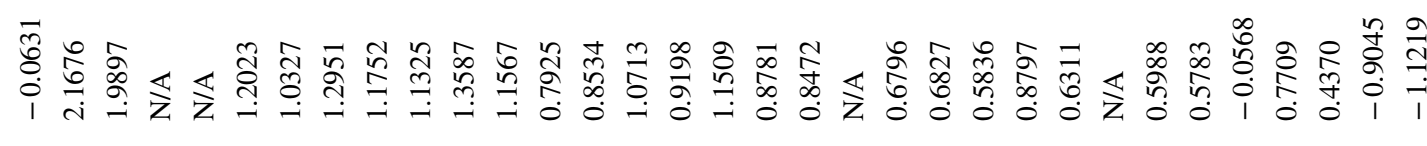 \\
\hline & 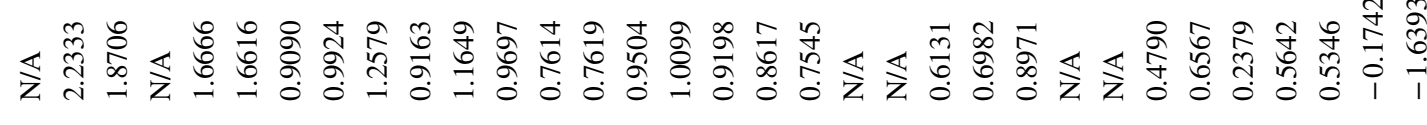 \\
\hline & 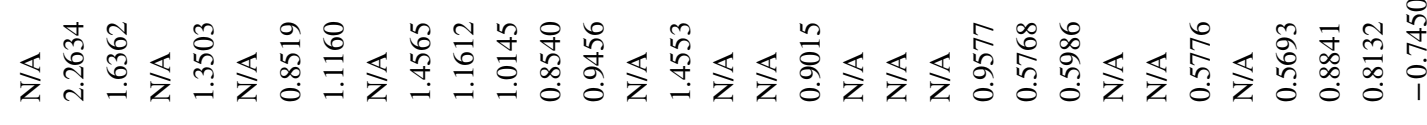 \\
\hline & 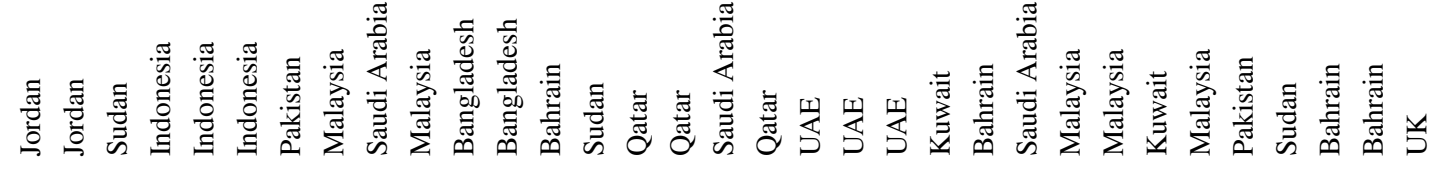 \\
\hline & 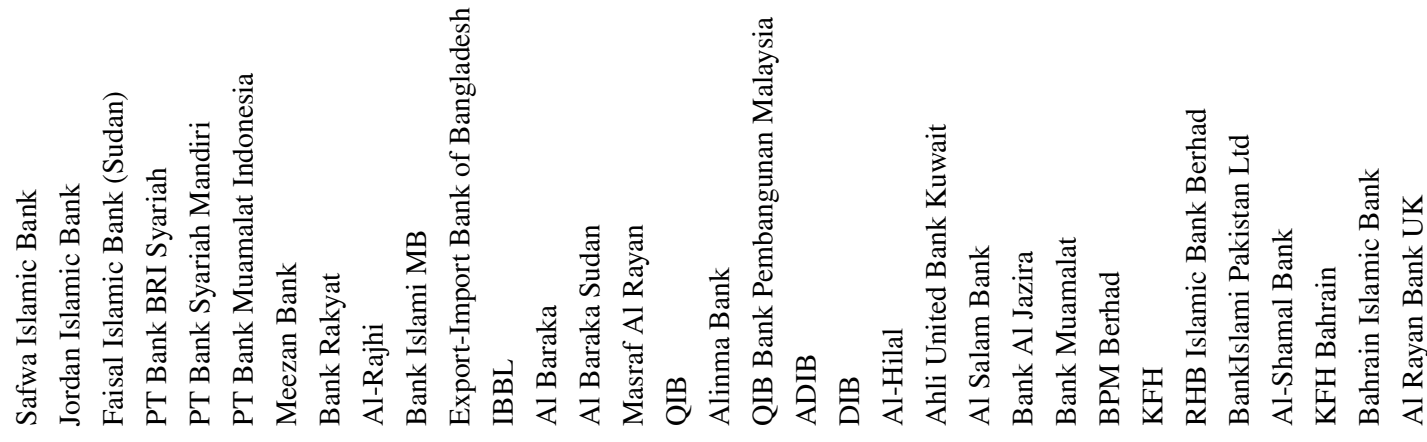 \\
\hline & \\
\hline
\end{tabular}


Table 5 Overall Maqasid performance of IBs at country level

\begin{tabular}{|c|c|c|c|c|c|c|c|c|c|c|c|}
\hline Country & 2008 & 2009 & 2010 & 2011 & 2012 & 2013 & 2014 & 2015 & 2016 & Average & $\begin{array}{l}\text { \% Change } \\
\text { between } 2008 \text { and } \\
2016\end{array}$ \\
\hline Jordan & 2.26 & 2.23 & 1.05 & 2.37 & 4.22 & 4.39 & 4.60 & 4.47 & 4.52 & 3.34 & 100 \\
\hline Indonesia & 1.35 & 1.66 & 1.20 & 2.42 & 1.10 & 1.24 & 1.36 & 1.31 & 1.37 & 1.44 & 1 \\
\hline Sudan & 1.05 & 1.07 & 1.20 & 1.23 & 0.83 & 1.21 & 1.12 & 1.14 & 1.50 & 1.15 & 43 \\
\hline Bangladesh & 1.09 & 1.07 & 1.26 & 1.02 & 1.03 & 0.98 & 1.03 & 1.02 & 0.97 & 1.05 & -3 \\
\hline Qatar & 1.46 & 0.94 & 0.96 & 0.90 & 0.85 & 0.87 & 0.88 & 0.87 & 0.91 & 0.96 & -38 \\
\hline Pakistan & 0.85 & 0.57 & 0.49 & 1.05 & 1.01 & 1.06 & 1.01 & 1.20 & 1.11 & 0.92 & 31 \\
\hline Saudi Arabia & 0.58 & 1.02 & 1.07 & 0.81 & 0.83 & 0.83 & 0.94 & 1.19 & 1.03 & 0.92 & 78 \\
\hline Malaysia & 0.94 & 0.86 & 0.91 & 0.90 & 0.90 & 0.87 & 0.90 & 0.92 & 0.93 & 0.90 & 1 \\
\hline UAE & 0.90 & 0.75 & 0.76 & 0.78 & 0.79 & 0.83 & 0.85 & 0.86 & 0.89 & 0.82 & 1 \\
\hline Kuwait $^{\mathrm{a}}$ & - & 0.55 & 0.64 & 0.66 & 0.79 & 0.84 & 0.83 & 0.85 & 0.86 & 0.75 & -56 \\
\hline Bahrain & 0.88 & 0.46 & 0.23 & 0.60 & 0.22 & 0.76 & 1.00 & 0.79 & 0.53 & 0.60 & 40 \\
\hline UK & -0.75 & -1.64 & -1.12 & -1.29 & -1.18 & -0.80 & -0.69 & -0.56 & -0.20 & -0.91 & 73 \\
\hline
\end{tabular}

${ }^{a}$ Average and change were calculated for 2009-2013

five best banks with the highest scores for their maqasid performance, whereas BankIslami Pakistan Limited (0.6438), Al-Shamal Bank (Bahrain) (0.5661), KFH Bahrain (0.5243), Bahrain Islamic Bank (0.0329) and Al Rayan Bank UK $(-0.9155)$ demonstrated the lowest scores. Overall, except for a high dispersion in safeguarding the 'wealth' maqasid corollary, no best practices were identified in the performance of IBs within other maqasid corollaries, which supports the findings of previous studies including, among others, Hassan (2012), Belal et al. (2014), Haniffa and Hudaib (2007) and others. Only a few IBs, which are in the top five maqasid performers, scored higher than half of the score in the maqasid indices.

As regards to country level performance, as can be seen in Table 5, Jordan scored the highest average maqasid performance index score of 3.34, followed by Indonesia (1.44) and Sudan (1.15). The three countries with a low IB maqasid performance index are Kuwait (0.75), Bahrain (0.60) and the United Kingdom (-0.91). Such a low maqasid performance from IBs in these two rich GCC countries supports criticism of the IBs, namely, that they are 'delivering a new capitalism to the Muslim world' which is oriented towards financialization rather than focusing on their social role (Asutay 2012, p. 108).

In addition, the performance of IBs per each maqasid corollary except $I_{7}$ (wealth), as IBs are inherently oriented towards financial performance, are presented in Fig. 2. As can be seen, mostly IBs in Indonesia, Bangladesh, Jordan and Pakistan are oriented towards safeguarding the 'self', 'posterity' and 'social entity' maqasid corollaries, which indicates their more active social and developmentalist role in these countries as opposed to the IBs in the GCC countries (Bahrain, Qatar, and Kuwait) and the UK. These results are consistent with Aksak and Asutay's (2015) findings regarding the poor role of IBs in the economic and social development of the GCC countries.

\section{Determinants of the Maqasid Performance of IBs: Econometric Analysis}

Table 6 presents the summary of the descriptive statistics. As can be seen, the mean of the overall $I_{\text {maqasid }}$ index is approximately 1.0284 while the range of this index is from a minimum of -1.6493 to a maximum of 6.7370 . Such wide dispersion in the $I_{\text {maqasid }}$ index is due to the wide spread of the $I_{7}$ (wealth) index component (from -14.0905 to 49.6030), which indicates that some IBs overperformed in financial terms, while others faced significant financial difficulties during the 2008-2016 period. Although the mean of the $I_{7}$ (wealth) index is approximately 5.2846, the mean of the $I_{\text {maqasid }}$ index is significantly lower as a result of the low scores in the other maqasid performance indices as components of the $I_{\text {maqasid }}$ index. Such indices as $I_{8}$ (ecology), $I_{4}$ (intellect), and $I_{6}$ (social entity) scored $0.1065,0.1711$ and 0.4162 , respectively, as these indices have minimum zero (0) scores, which indicates that some IBs did not undertake any actions in these maqasid corollaries during 2008-2016. Furthermore, the most surprising finding is the low $I_{1}$ (faith) index mean score (0.3791), which is in contrast to the expectation that IBs are niche financial institutions that are expected to serve the financial needs of people according to Islamic expectations. Thus, low $I_{\text {maqasid }}$ index is an indication of the low scores prevailing throughout the sample banks and periods as well as dimensions. 


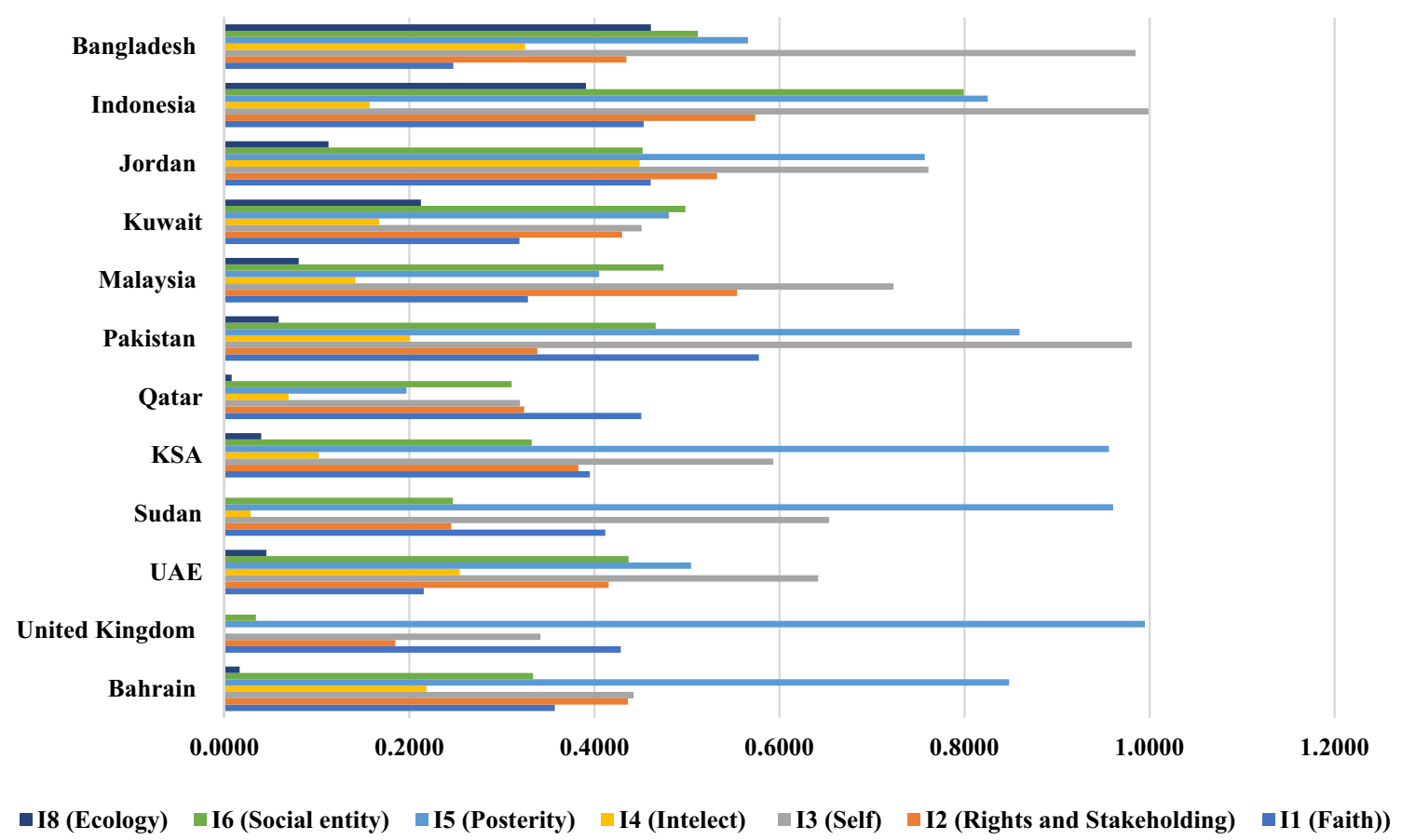

Fig. 2 Performance of individual Maqasid dimension of IBs in the sampled countries

As can be seen from Fig. 3, the Jarque-Bera, skewness and kurtosis coefficients are approximately 37,764.748, $3.113,241$ and $20.08,921$, respectively, for the $I_{\text {maqasid }}$ distribution, which indicates that the distribution is not normal. ${ }^{3}$ Nevertheless, a judgment can be made in favour of the normal distribution for this particular dependent variable. In addition, according to Brooks (2008, pp. 44, 164), an indication of non-normality for the distribution is not a significant concern for the purpose of determining the Best Linear Unbiased Estimator (BLUE) estimators using OLS if other assumptions are valid. Therefore, non-normality in dependent variables is not considered a restriction to our regression model.

The efficient conduct of a regression analysis requires the absence of multicollinearity; therefore, in this study, Pearson's Correlation was utilised to explore the presence of multicollinearity in the relationship between dependent, independent and control variables. According to Gujarati (2003, p. 359), the pair-wise correlation between explanatory variables in excess of \pm 0.8 creates a serious multicollinearity problem. As presented in Table 7, a significant pair-wise correlation can only be found between $I_{\text {maqasid }}$ and $I_{7}$ indices (0.9529), which is not the main aim of this study. All other pair-wise correlations between variables are found to be less than 0.8 , which helps to conclude that

\footnotetext{
3 The results for other variables can be made available upon request as due to length issue they are not presented here.
}

multicollinearity is not an issue for the pooled regression, FEM, REM models presented in this paper.

As this study is based on unbalanced panel data, several statistical tests were performed, including the simple OLS 'pooled regression', redundant fixed effect test, the random effect model (REM), the fixed effect models (FEM) according to the existing literature on econometrics (see: Brooks 2008; Gujarati 2003) (Table 7).

Tables 8 and 9 present the redundant fixed effect and Hausman test, which had the null hypothesis that no crosssectional and period specific fixed effects exist, along with no significant difference between FEM and REM estimators. Since the results reject the null hypothesis, the FEM should be considered as an appropriate model for the purpose of this study. In addition, following the recommendation by Gujarati (2003, p. 418), White's robust standard errors test in FEM was run in order to prevent the potential negative influence of heteroscedasticity, ${ }^{4}$ which is also supported by the higher adjusted $R^{2}$ coefficient (0.7134), as shown in Table 10 as an indicator that a significant part of the variation of the $I_{\text {maqasid }}$ index is explained in comparison with other models. Nevertheless, the empirical results section presents all four models (pooled regression, REM, FEM, and FEM with robust standard errors test) since Gujarati (2003, p. 651) argues that "panel data do not provide a cure-all for all of an econometrician's problem".

\footnotetext{
$\overline{4}$ The results for the sub-categories can be provided upon request as due to length issue they could not be presented here.
} 
Table 6 Descriptive statistics of the variables

\begin{tabular}{|c|c|c|c|c|c|c|c|}
\hline Variables & Mean & Median & Maximum & Minimum & SD & Skewness & Kurtosis \\
\hline \multicolumn{8}{|c|}{ Panel A: dependent variables } \\
\hline IMAQASID & 1.0284 & 0.8941 & 6.7370 & -1.6493 & 0.9703 & 3.1132 & 20.0892 \\
\hline$I_{1}$ & 0.3791 & 0.3816 & 0.7666 & 0.0667 & 0.1624 & 0.0682 & 2.2445 \\
\hline$I_{2}$ & 0.4201 & 0.4521 & 0.7435 & 0.1274 & 0.1464 & -0.1247 & 1.7870 \\
\hline$I_{3}$ & 0.6533 & 0.6324 & 1.0000 & 0.0339 & 0.2902 & -0.1391 & 1.6326 \\
\hline$I_{4}$ & 0.1711 & 0.1154 & 0.5614 & 0.0000 & 0.1534 & 0.7019 & 2.6386 \\
\hline$I_{5}$ & 0.7157 & 0.3853 & 9.4652 & -1.1011 & 1.2935 & 4.3322 & 24.2664 \\
\hline$I_{6}$ & 0.4162 & 0.4231 & 0.8462 & 0.0000 & 0.2132 & 0.0264 & 2.3034 \\
\hline$I_{7}$ & 5.2846 & 4.3555 & 49.603 & -14.0905 & 7.2247 & 3.4466 & 23.0413 \\
\hline$I_{8}$ & 0.1065 & 0.0000 & 0.8000 & 0.0000 & 0.1926 & 2.0204 & 6.1226 \\
\hline \multicolumn{8}{|c|}{ Panel B: independent variables } \\
\hline HDI & 0.7358 & 0.7970 & 0.9200 & 0.4470 & 0.1305 & -0.9522 & 2.4970 \\
\hline GDP & 3.4600 & 1.9900 & 3.0200 & 2.2000 & 5.0100 & 3.5322 & 16.9488 \\
\hline FD & 0.4202 & 0.4289 & 0.8888 & 0.0877 & 0.1842 & 0.0025 & 2.6331 \\
\hline PCR & 10.0100 & 11.0000 & 14.0000 & 2.0000 & 2.9395 & -0.5984 & 3.0438 \\
\hline CIVLAW & 0.4197 & 0.0000 & 1.0000 & 0.0000 & 0.4944 & 0.3253 & 1.1058 \\
\hline COMLAW & 0.6313 & 1.0000 & 1.0000 & 0.0000 & 0.4833 & -0.5244 & 1.2966 \\
\hline SHARLAW & 0.9562 & 1.0000 & 1.0000 & 0.0000 & 0.2050 & -4.4586 & 20.8791 \\
\hline MUSLIMRATIO & 0.7957 & 0.8120 & 1.0000 & 0.0270 & 0.1886 & -2.1686 & 9.5258 \\
\hline GOV & 0.3293 & 0.0000 & 1.0000 & 0.0000 & 0.4141 & 0.7555 & 1.8363 \\
\hline FAM & 0.1614 & 0.0000 & 1.0000 & 0.0000 & 0.2967 & 1.4869 & 3.6759 \\
\hline INST & 0.5218 & 0.5000 & 1.0000 & 0.0000 & 0.3416 & -0.0807 & 1.8381 \\
\hline FORG & 0.2281 & 0.0000 & 0.7500 & 0.0000 & 0.3040 & 0.7062 & 1.7412 \\
\hline INED & 0.3600 & 0.3636 & 1.0000 & 0.0000 & 0.2960 & 0.3256 & 2.0693 \\
\hline BPSD & 0.1520 & 0.1538 & 0.8000 & 0.0000 & 0.1607 & 1.3854 & 6.0815 \\
\hline BS & 9.1368 & 9.0000 & 23.0000 & 0.5000 & 2.9835 & 0.6099 & 5.7906 \\
\hline CEOD & 0.9854 & 1.0000 & 1.0000 & 0.0000 & 0.1201 & -8.0941 & 66.5148 \\
\hline IAH & 5.8891 & 5.4995 & 17.7262 & 0.0289 & 3.6230 & 0.4704 & 2.4924 \\
\hline SSBC & 4.6788 & 4.0000 & 14.0000 & 2.0000 & 2.2980 & 2.0235 & 7.3164 \\
\hline SSBD & 0.6124 & 0.6667 & 0.8947 & 0.0000 & 0.2302 & -1.2476 & 3.8551 \\
\hline SSBCM & 0.6961 & 0.7500 & 1.0000 & 0.0000 & 0.3295 & -0.8972 & 2.4606 \\
\hline \multicolumn{8}{|c|}{ Panel C: control variables } \\
\hline SIZE & 9783.7 & 4875.616 & $84,165.24$ & 7.1300 & $13,865.67$ & 2.7262 & 11.9245 \\
\hline LEV & 8.4968 & 8.0841 & 18.0744 & 0.2049 & 3.9622 & 0.1943 & 2.3506 \\
\hline AGE & 21.5 & 1988 & 2008 & 1954 & 13.3145 & -0.3880 & 2.5605 \\
\hline
\end{tabular}

$N=274$ observations; $I_{1}$ : faith; $I_{2}$ : rights and stakeholding; $I_{3}$ : self; $I_{4}$ : intellect; $I_{5}$ : posterity; $I_{6}$ : social entity; $I_{7}$ : wealth; $I_{8}$ : ecology

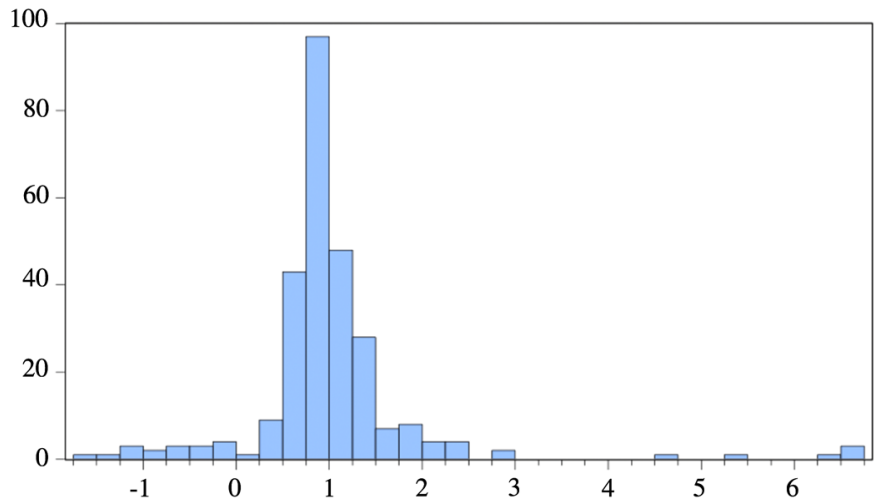

Series: IMAQASID

Sample 20082016

Observations 274

1.028417

Median $\quad 0.894100$

Maximum $\quad 6.737013$

Minimum $\quad-1.640000$

Std. Dev. $\quad 0.970316$

Skewness $\quad 3.113241$

Jarque-Bera $\quad 3776.748$

Probability $\quad 0.000000$ 


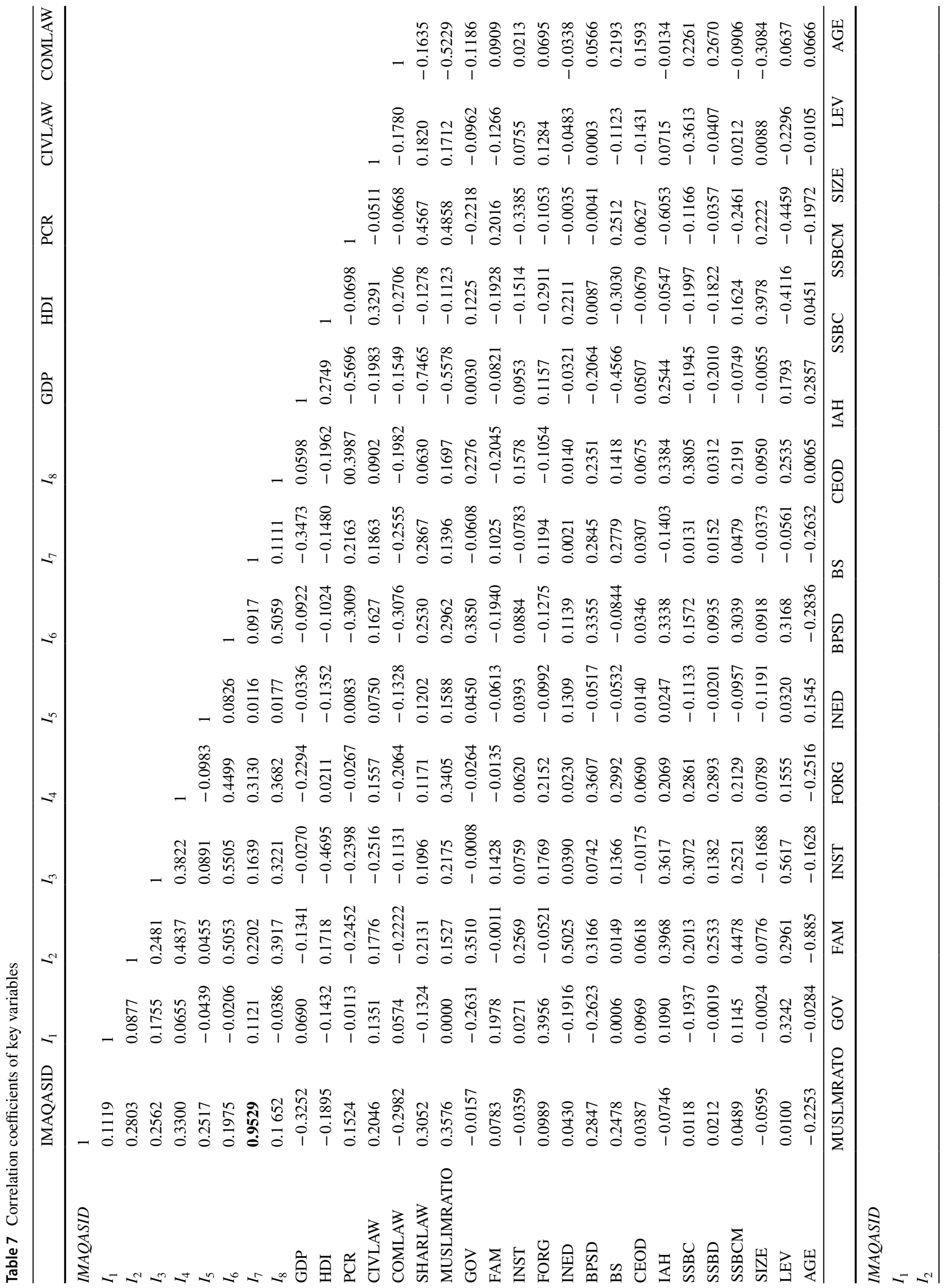




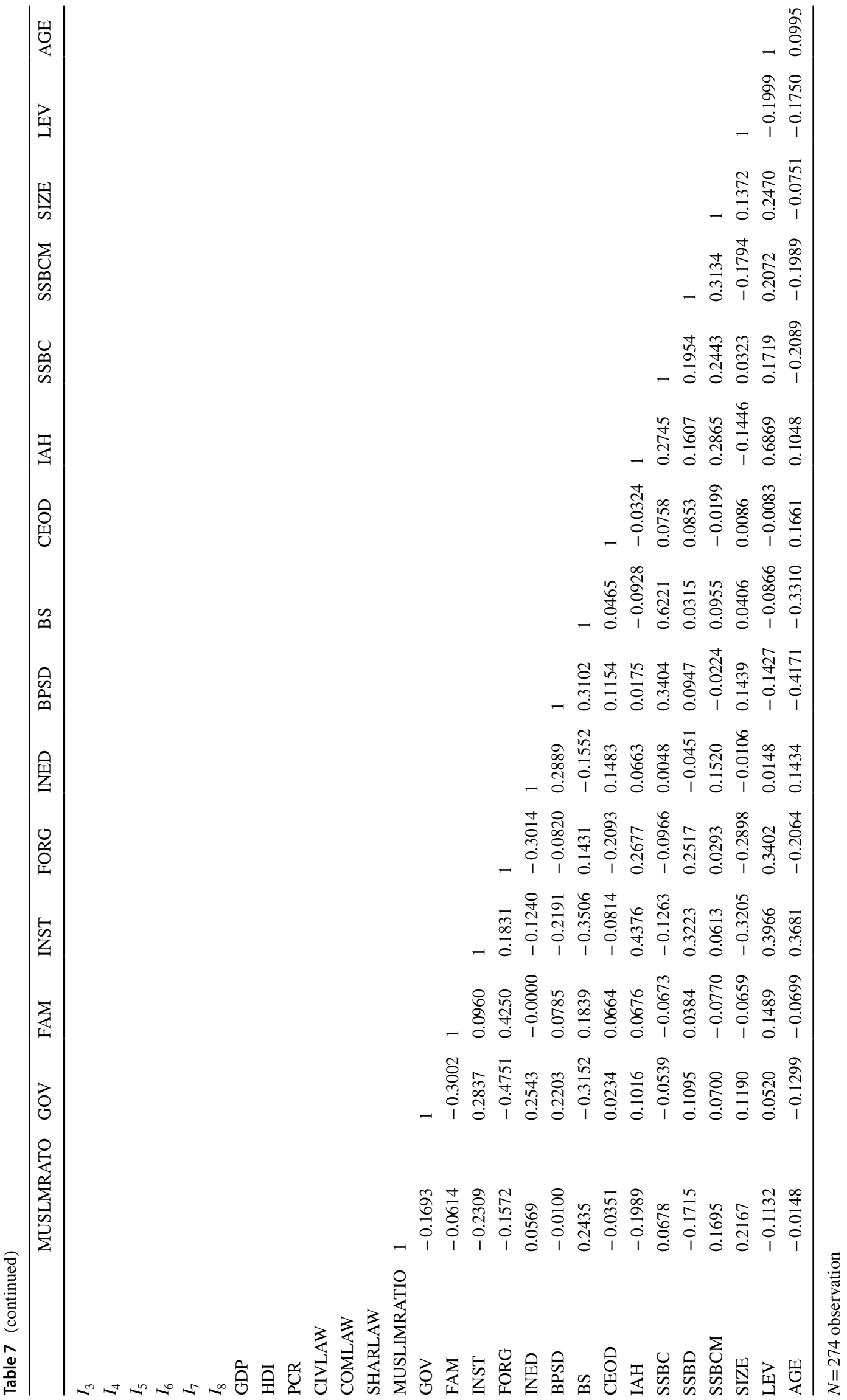


Table 8 Result of the redundant fixed effect test

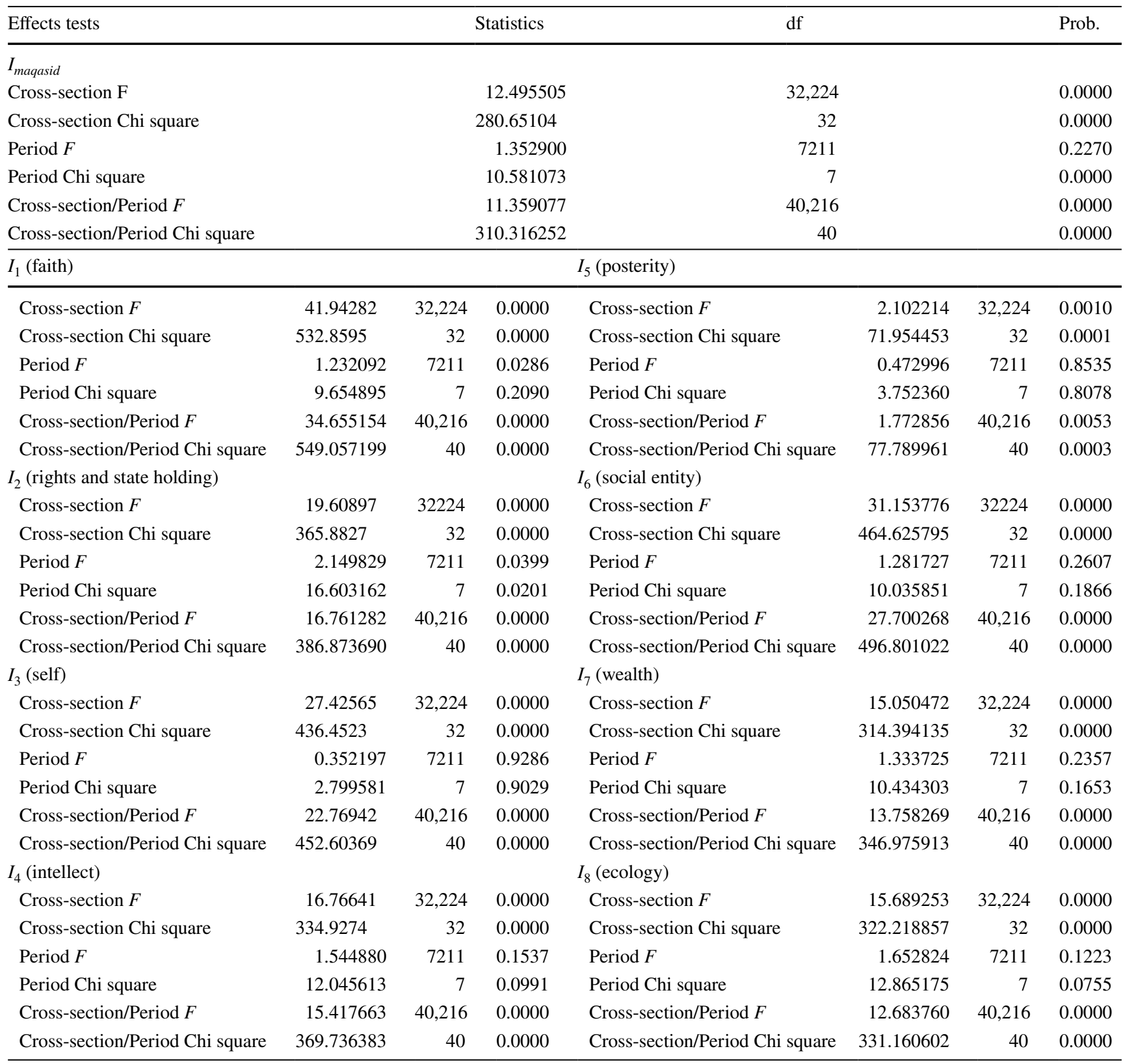

Table 9 Hausman test results

\begin{tabular}{lrlll}
\hline Cross-section random & $\chi^{2}$ statistic & $\chi^{2}$ df & Prob. & Conclusion \\
\hline$I_{\text {maqasid }}$ & 27.12853 & 17 & 0.0562 & H0-not rejected, fixed effect model \\
$I_{1}$ (faith) & 24.85788 & 17 & 0.0979 & H0-not rejected, random effect model \\
$I_{2}$ (rights and stakeholding) & 62.98078 & 17 & 0.0000 & H0-rejected, fixed effect model \\
$I_{3}$ (Self) & 47.58493 & 17 & 0.0001 & H0-rejected, fixed effect model \\
$I_{4}$ (intellect) & 49.91844 & 17 & 0.0000 & H0-rejected, fixed effect model \\
$I_{5}$ (posterity) & 18.40060 & 17 & 0.3640 & H0-not rejected, random effect model \\
$I_{6}$ (social entity) & 37.10761 & 17 & 0.0033 & H0-rejected, fixed effect model \\
$I_{7}$ (wealth) & 26.07010 & 17 & 0.0732 & H0-rejected, fixed effect model \\
$I_{8}$ (ecology) & 132.83777 & 17 & 0.0000 & H0-rejected, fixed effect model \\
\hline
\end{tabular}




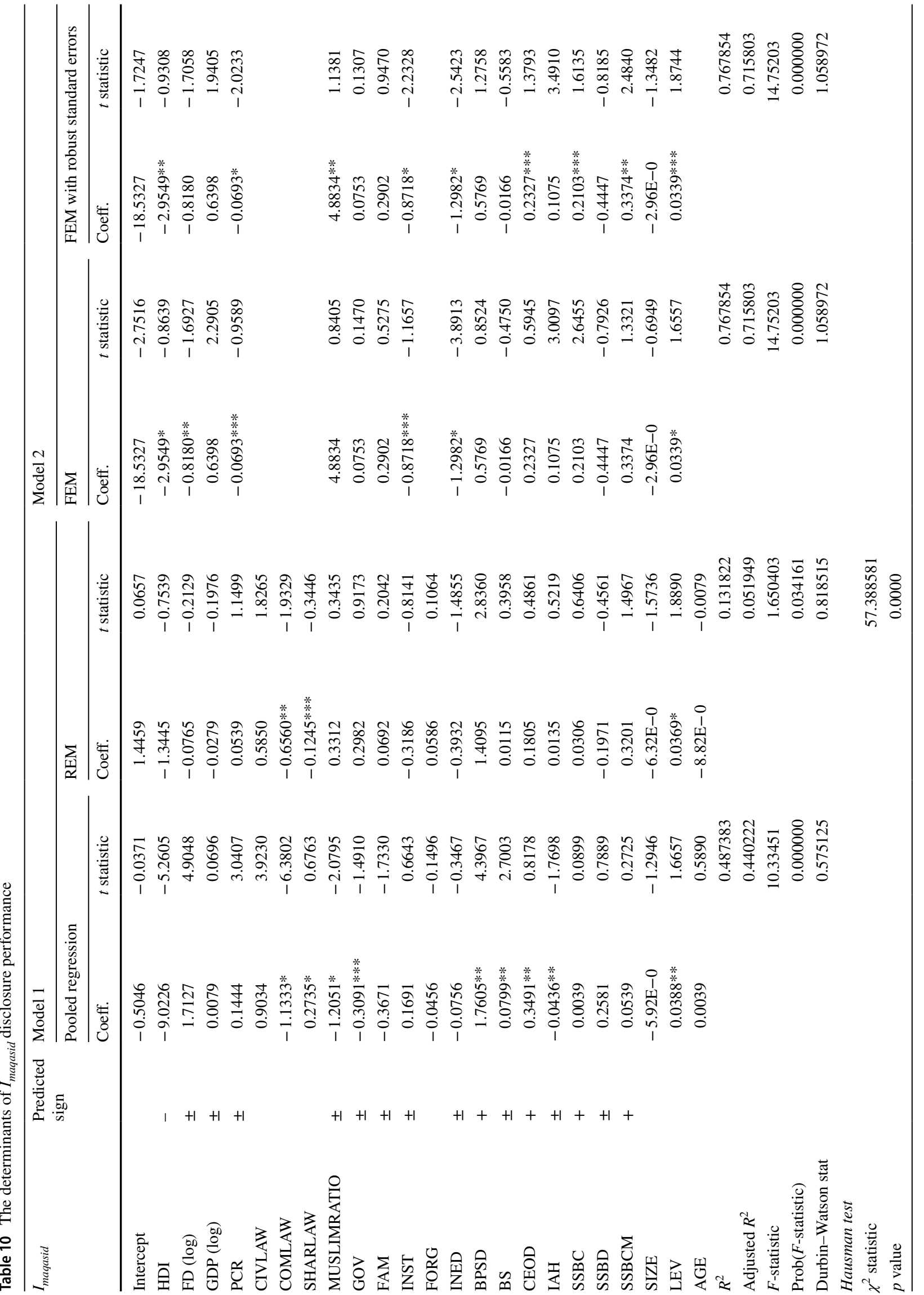




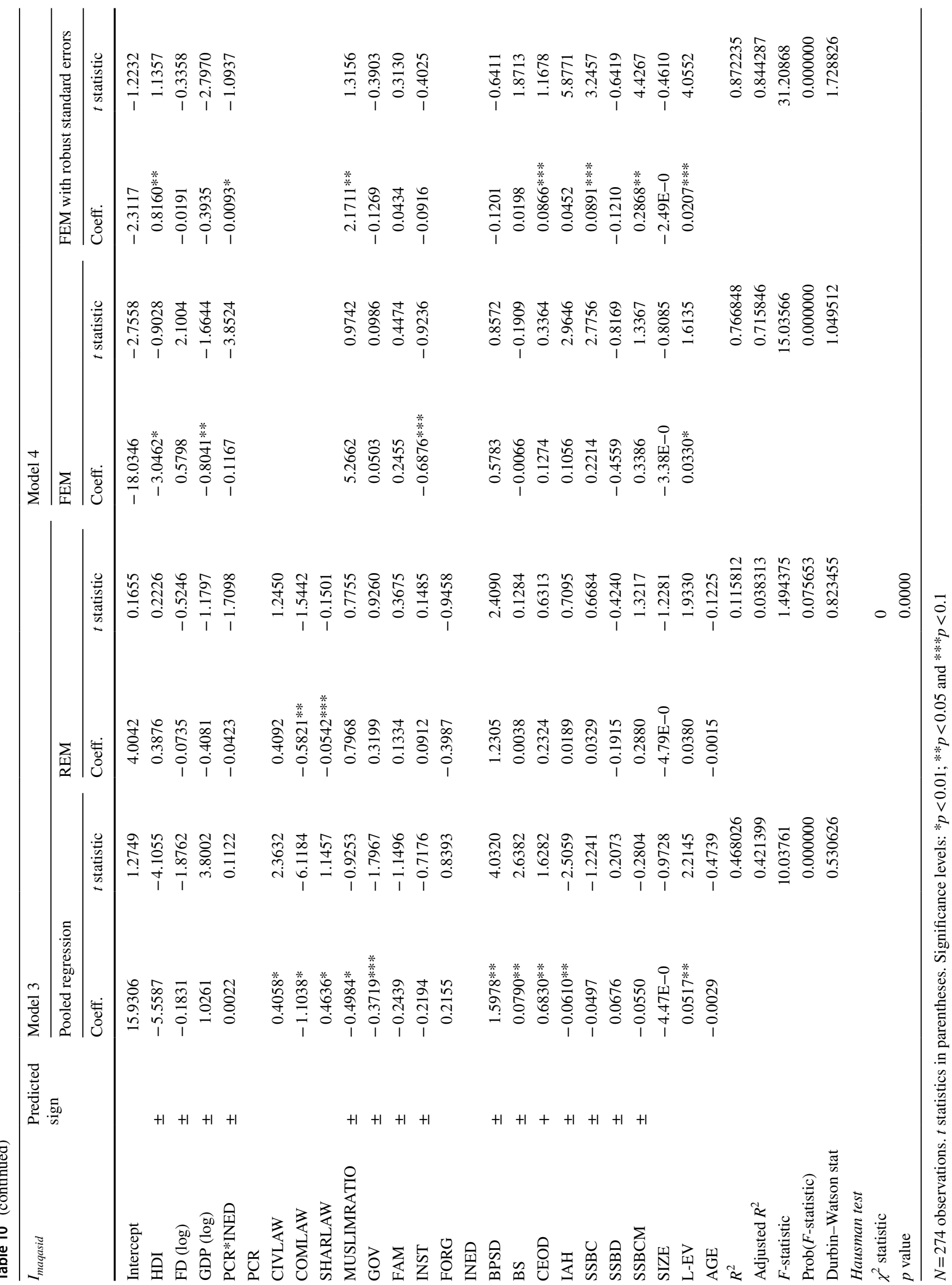


Due to the specifics of the FEM model, which inherently includes differential intercept dummies, Eviews, the econometrics package, removed four dummy variables (CIVLAW, COMLAW, SHARLAW and FORG) in order to prevent a 'dummy variable trap' or perfect collinearity (as stated by Gujarati 2003, p. 642).

Table 10 presents the results of the panel data analysis using all models for overall maqasid performance index, $I_{\text {maqasid. }}{ }^{5}$ The results are presented in the form of 'Pooled Regression Model', 'random effect model (REM)', 'fixed effect model (FEM)' and 'FEM with Robust Standard Errors' for four models. While Model 1 tests all the variables included in the model with Pooled Regression and REM, Model 2 presents the results with FEM and FEM with Robust Standard Errors in which CIVLAW, COMLAW, SHARLAW and MUSLIMRATIO as well as FORG and AGE are excluded. In an attempt to locate the effect of corporate governance (GOV, BPSD, BS and CEOD) on maqasid performance by political and socio-economic environment (COMLAW, SHARLAW and MUSLIMRATIO), interaction variables between the corporate governance and political and socio-economic variables are introduced. The results for these presented in Table 10 as Model 3 and Model 4 in a similar way with Model 1 and Model 2. According to the results of FEM with the robust standard errors model, several political and socio-economic context related variables, ownership structure, corporate governance, and SSB variables all influence the maqasid performance of IBs. Concerning interaction variables in models 3 and 4:

As can be seen, the impact of HDI $(-4.9606)$ is negative and statistically significant with $p=0.3529$, which confirms the finding by Jones (1999); hence hypothesis $\mathrm{H}_{1}$ is not rejected. A possible explanation for this might be the active role of the government and regulators in enhancing ethical, social and environmental activities by IBs as additional resource providers for solving country-specific issues as well as the customers' proactive positions. As a result, it is expected that IBs in low HDI index countries should expand their socio-ethical-economic activities in line with maqasid to fulfil the requirements of their regulators, minimize pressure from other stakeholders, and legitimize their role in society as active players in solving social and environmental problems.

For solving the non-linear relationship between dependent and independent variables, the macroeconomic variables of GDP and financial development (FD) were logarithmically transformed in order to preserve the linear model. The results show that FD has a negative significant impact on

\footnotetext{
5 The regression results of the performance for each maqasid corollary can be made available upon request as due to the length of the article they could not be presented here.
}

maqāsid ( -0.8180 with $p=0.0974$ ) which is not surprising as the financial development variable in market economies has been determined by fundamental shifts towards a market-based financial system and its stability, but not by social expectations. Similarly, re-estimating the panel including the interaction variable between corporate governance (INED) and political variables (PCR) (PCR*INED), GDP also shows a significant negative impact $(-0.8041$ with $p=0.0368)$ on maqāsid performance.

As the results depicted in Table 10 demonstrates, MUSLIMRATIO $(4.8834, p=0.2563)$ is one of the main contributors to the higher maqasid performance of IBs, which is consistent with previous studies (such as Rizkiningsih and Dewi 2015), which implies that hypothesis $H_{4}$ should not be rejected. This can be interpreted as IBs being niche-oriented financial institutions, and hence their activities are dependent on the 'relevant public' to whom they are accountable.

The last environmental factor which has a negative sign and is statistically significant at the $5 \%$ level $(p=0.0442)$ is PCR $(-0.0693)$. This finding agrees with Farook et al.'s (2011) findings, which showed that PCR has a negative impact on the level of social disclosure as a proxy of the social activity of IBs. Therefore, hypothesis $\mathrm{H}_{2}$ is not rejected by the regression model.

Turning to the ownership and corporate governance variables, the results in this study indicate that both the INST ( -0.8718 with $p=0.0265)$ and $\operatorname{INED~}(-1.2982$ with $p=0.0117$ ) variables have a negative sign and are significant at the $1 \%$ level, indicating their impact on maqasid performance, while CEOD $(0.2327$ with $p=0.0869)$ has a positive impact and is significant only at the $10 \%$ level. This is in contrast to Kunapatarawong and Martinez-Ros (2013), who found that institutional pressure has a positive but statistically insignificant impact on social performance.

The findings in this study show the negative effect of institutional investors on overall maqasid-based disclosure performance, which might be due to the incentives of institutional investors to increase benefits by reducing costs on social activities, which could result in IBs facing reputational issues from depositors following the negative impact on financial performance. Furthermore, the negative impact of institutional investors on financial performance was also identified by Zouari and Taktak (2012). The same reasons could be suggested for the negative influence of INED variables as the main objective of INEDs in any board of directors is mostly to protect the interest of shareholders rather than of stakeholders, which may result in INEDs pressuring IBs to provide more benefits to shareholders, thus leading to a decrease in social activity and indirectly causing the deterioration of the image and financial performance of the IBs. However, the findings in this study contrast with Zeitoun (2013), who argued that most of the studies found positive relationships between board independence and the social 
performance of corporations. Nevertheless, as the findings in the present study indicate, hypotheses $H_{5}$ and $H_{6}$ are not rejected.

Furthermore, positive but statistically insignificant results are found for the GOV and FAM variables, which differ with those in Zouari and Taktak's (2012) study, as the latter found a positive and significant relationship between these variables and financial performance.

As can be seen in Table 10, two of the three SSB-related variables such as SSBC (0.2103) and SSBCM (0.3374) have a positive and statistically significant impact with $p=0.0087$ and $p=0.0137$ while SSBD $(-0.4447$ with $p=0.4288$ ) is not statistically significant. These outcomes support Farook et al.'s findings (2011) who argued that a 'number of members' increase monitoring capacity of SSB and positively impact the level of Shari'ah compliance in IBs' activities. Therefore, hypothesis $H_{7}$ should not be rejected.

From the control variables, only LEV (0.0339 with $p=0.0622$ ) is found to be statistically significant at the $10 \%$ level with a positive sign, while SIZE and AGE are found to be statistically insignificant, which is consistent with the results of Oikonomou et al. (2012). It should be noted that for Islamic banking, this implies that the high level of leverage is due to higher liabilities as the main source of leverage comes from customer deposits (no interbank loans are allowed for IBs), which makes IBs concentrate on social and ethical aspects in addition to financial performance since any deterioration of the public image of IBs may significantly impair their financial stability.

The interaction variables between corporate governance and COMLAW, CIVLAW, and SHARLAW through dummy variables were created for Model 3 and Model 4; however, none of them were significant. In addition, an interaction variable was created between corporate governance (INED) and political variable (PCR) (PCR*INED) across four regressions in Model 3 and Model 4, which is only significant with FEM with Robust Standard Errors in Model 4.

In order to test the robustness of the model, a robustness check was performed on the presence of dynamic features in the model. We tested the effect of a one-year time lag $(-1)$ on maqasid disclosure performance, as Mirzaei (2011) found that the financial performance of IBs is influenced by period lag variables. Considering this dynamic behaviour of the financial performance of IBs, a separate regression model including the time lag variable was run. In this dynamic panel data analysis, the findings remained unchanged for the HDI, MUSLIMRATIO, and INST independent variables. However, CEOD and other SSB-related variables were found to be statistically insignificant, whereas the results were changed for BPSD and BS, both of which were found to have a negative impact. Such change may be explained by a significant dynamism in changes to the board of directors while SSB-related variables are mostly stable in IBs. Therefore, our main findings remain as stated in the main regression model.

To test for potential endogeneity between corporate governance performance and socio-economic performance, the Durbin-Wu and Hausman tests were applied. In a statistical model, endogeneity may occur as a result of joint determination between independent (corporate governance) and dependent (maqāsid) variable, or omitted variables, or if there is a correlation between explanatory variables and the error term (Greene 2003). The results in Table 10 indicate that the F-test is not significant and thus the null hypothesis of the Durbin-Wu test cannot be rejected, confirming that endogeneity does not represent a problem (Gujarati 2003) in this research.

\section{Conclusion}

This study explored the maqasid performance of IBs based on the argument developed by the IME theoretical framework that the operation of IBs should be driven by the maqasid paradigm. With the subsequent identification of its main determinants; several hypotheses were developed and tested with the data generated from a disclosure analysis along with a number of other variables. As a result, several important findings were identified.

The findings established by this study show that political and socio-economic factors (HDI, PCR and MUSLIMRATIO) as determinants of environmental external influence are found to be most significant in their potential impact on the maqasid performance of IBs, which indicates that the application of the maqasid concept in IB activities is mostly dependent on socio-economic realities within the respective countries and local communities. At the same time, it may also be driven by the main external stakeholders such as regulators, depositors and society itself. This implies that IB activities are highly dependent on current issues within each society, for which each society can contribute in tackling 
them to gain 'legitimization' (Dusuki 2008) for their existence along with their Shari'ah compliance. In addition, facing limitations in their markets along with competition from conventional banks, such 'legitimacy' could protect them from reputational risks and encourage safe depositors' to be their customers. Any loss of such 'legitimacy' could negatively influence the financial performance and the stability of IBs as depositors could withdraw their funds in cases where Shari'ah compliance is compromised in an IB's operations, as discovered by Chapra and Ahmed (2002). Thus, the combined contrasting results of the hypotheses regarding the influence of the Muslim population and the HDI demonstrate the necessity of understanding the broader political and socio-economic realities in order to improve the maqasid performance of IBs.

The internal IB-related factors also have a significant impact on the maqasid performance of IBs. The identified issues within ownership structure, and corporate and Shari'ah governance should particularly be noted. Whereas SSB-related factors positively impact the maqasid performance of the sampled IBs (SSBC's and SSBCM's coefficients are 0.2103 and 0.3374 , respectively), which is expected from the authoritative bodies of Shari'ah scholars within IBs, these are mitigated by the more significant negative influence of independent directors $(-1.2982)$ and institutional investors $(-0.8718)$. This alliance of independent directors and institutional investors, both of which have the same objectives of higher dividends and increased shareholder value, could influence SSBs to engineer Shari'ah compliancy rather than Shari'ah-based decisions or otherwise restrict the abilities of SSBs or Shari'ah auditors to find any non-Shari'ah compliant income to be disposed of to charitable social activities, which is one of the elements of maqasid performance. Therefore, it could be argued that Shari'ah and corporate governance issues within IBs should be subject to further review by academic scholars and other stakeholders.

In reflecting on this research and the findings, the importance of embedded faith or the religiosity of leadership in actualising IME in the operations of IBs must also be acknowledged, as such a quality would consider and locate the institution of IBs within its social formation, namely, in actualising the maqasid al-Shari'ah expectations. In recent years, the burgeoning literature on Islamic leadership, including the qualities of leaders vis-à-vis Islam is being developed (see: Ali 2009; Beekun 2012; Toor 2008). The importance of the quality of ethical or religious leadership in ensuring that the vision and mission as well as other aspects of the operations of IBs remain within ethically accepted frames and produce such outcomes and consequences as identified by maqasid al-Shari'ah is crucial. Considering that ethical values searched in IBs are the articulation of such values of the staff in the organisation, as organisations do not have their identity beyond the participants in the institution. In this spiritually constituted leadership and its articulations in shaping and effecting the operation of the IBs are indeed important. In particular, the distinction between contemplation and action in religious behaviour (Nasr 1978) and its impact on the operations of IBs can be a source of concern in the ethicality of the operations of these banks, which is evidenced with the low maqasid performance scores in this study and other studies outlined in the literature review discussed earlier. However, this research could not delve into leadership debates to demonstrate its impact on delivering IME expectations as articulated in maqasid al-Shari'ah; as that requires another set of variables and measurement issues which was not possible to explore within the remit of this paper.

A critical reflection should also be provided as to whether the disclosed information represents the actual or lived reality. This is valid for all the studies which are based on disclosed information, as disclosed information does not imply that they have actually been 'lived' nor does it represent the truth always, as 'pretentious statements' can be an issue. This, for example, was the case with a number of financial companies during the 2008 financial crisis, as their disclosed positions indicated that they were in a healthy position while in reality their financial state was not healty. In the same manner, in the case of voluntary disclosure, 'non-disclosed information' does not imply that omitted or non-disclosed activities have not been 'lived' as disclosure is a cultural matter and is related to democratic governance practices at macro level in a country which have not taken root in Muslim countries where Islamic finance has some presence. Furthermore, it can be argued that disclosing information at individual level relating to charitable giving, for example, may not spiritually be considered a good practice within Islamic tradition, as 'whatever the goodness' is made should be kept secret to attain spiritual quality or piety (taqwa). However, considering that IBs are corporations which do not carry real personality, this spiritual guidance may not apply to them. 
In referring to the observed divergence between the aspirations of IME augmented maqasid al-Shari'ah, corporate accountability (Zadek et al. 2013) can be considered as an important correction mechanism. Therefore, the newly emerging Shari'ah audit field should be an important step in the right direction. However, the current Shari'ah audit practices in IBs still remains within Shari'ah compliance or form oriented audit based on figh rather than accounting for moral consequences of IB operations in the form of corporate accountability. Therefore, augmenting the current Shari'ah audit practices with the IME paradigm will help to develop authentic corporate accountability for IBs (Shafii et al. 2015; Shafii and Salleh 2010).

It should also be noted that in a global world where the conventional practices beyond Islamic morality is prevalent, the meaning of the niche area of maqasid as a measure of ethicality can be questioned in terms of its relevance. Despite the ontological differences, making references to the consequences of each of the prevailing practices such as SDGs (Sustainable Development Goals), ESG (Environmental, Social, Governance), SRI (Socially Responsible Investment), Impact Investment etc., a common and global understanding should be reached. In other words, IME and its maqasid consequences are based on Islamic ontology, while the consequences produced by maqasid are in line with the consequences of SDGs, ESG, SRI and Impact Investment (Asutay 2019). Hence, maqasid when presented in a systematic manner through consequentialism can bring about convergence with different practices despite its divine ontological positioning. Nevertheless, the Value Based Intermediation for Islamic Financial Institutions proposed in 2017 by Bank Negara Malaysia (the central bank of Malaysia) can be considered as another key development in the right direction to shape the future of IBFIs in a more humane sense by considering the interests of other stakeholders beyond capital, which is attempted by this study by specifically developing and testing MSI.

Overall, the findings identified in this study have several potential policy implications for IBs and regulators alike. While macro-environmental factors are difficult to change, improvements in internal corporate and Shari'ah governance structures may enhance maqasid orientation and the performance of IBs for the benefits of wider stakeholders within society. As previous studies have highlighted the advantages of a 'robust Shari'ah governance regime' (Ahmed 2011c) to ensure Shari'ah compliance in IB activities, this study further expands this position to strengthen internal SSBs within IBs through regulations from relevant national Shari'ah bodies or regulators for the purpose of increasing the social, ethical, environmental and financial performance of IBs rather than just being limited to serving shareholder needs.

In particular, the findings related to the board of directors' and SSBs' influence on maqasid disclosure performance could be further investigated, especially considering the 'conflict' between their objectives, as the board of directors should serve the interests of shareholders while SSBs should protect the interests of a wider group of stakeholders. Therefore, the application of game theory in corporate and Shari'ah governance could be an interesting subject for future research. In relation to this, the regulation of Shari'ah-related issues in different jurisdictions and its indirect influence on maqasid performance is also worthy of empirical investigation.

In concluding, since maqasid al-Shari'ah provides endogenous norms for IBs to shape their operations with, the findings revealed in this study clearly delineates that IBs have not yet shaped their operations in line with the expected maqasid outcomes. While IBs have demonstrated unprecedented success in their financial transformation in the form of asset accumulation, financial performance and institutional and geographic diffusion, their main objective of contributing to social good in the creation of 'good' or 'ihsani' society, namely, societal transformation, is yet to be fulfilled.

\section{Compliance with Ethical Standards}

Research Involving Human and Animal Rights This article does not contain any studies with human participants or animals performed by any of the authors.

Open Access This article is distributed under the terms of the Creative Commons Attribution 4.0 International License (http://creativeco mmons.org/licenses/by/4.0/), which permits unrestricted use, distribution, and reproduction in any medium, provided you give appropriate credit to the original author(s) and the source, provide a link to the Creative Commons license, and indicate if changes were made. 


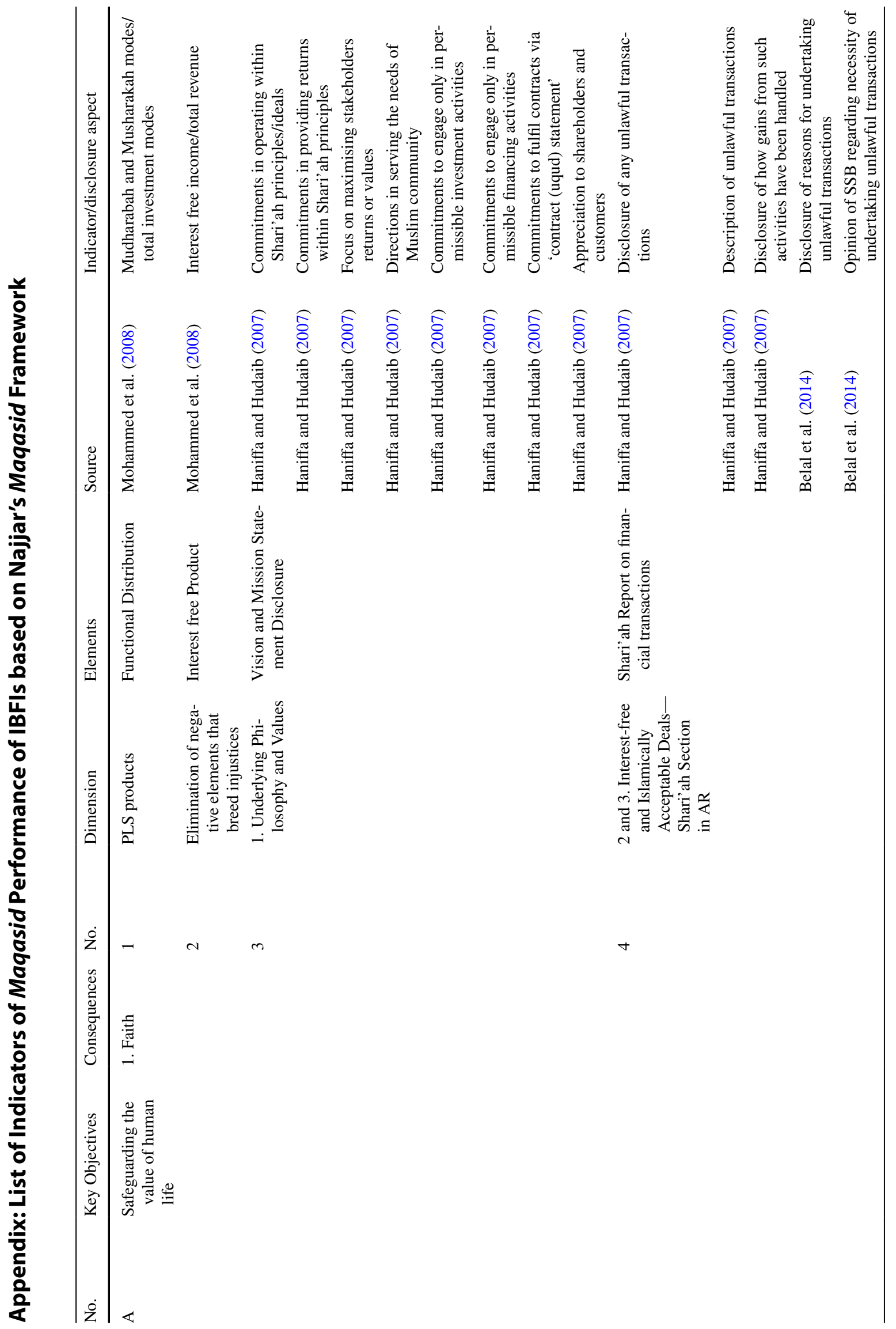




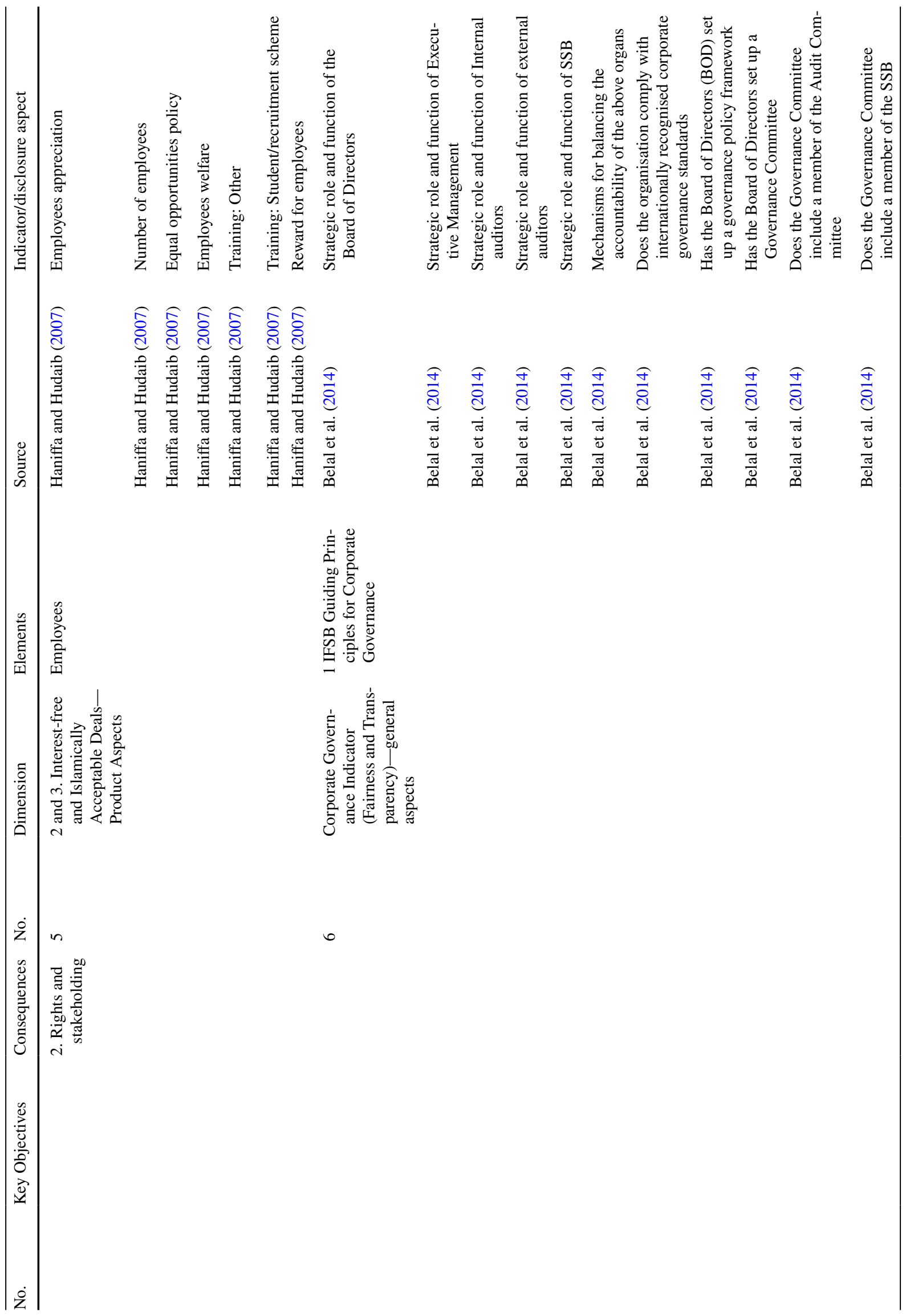




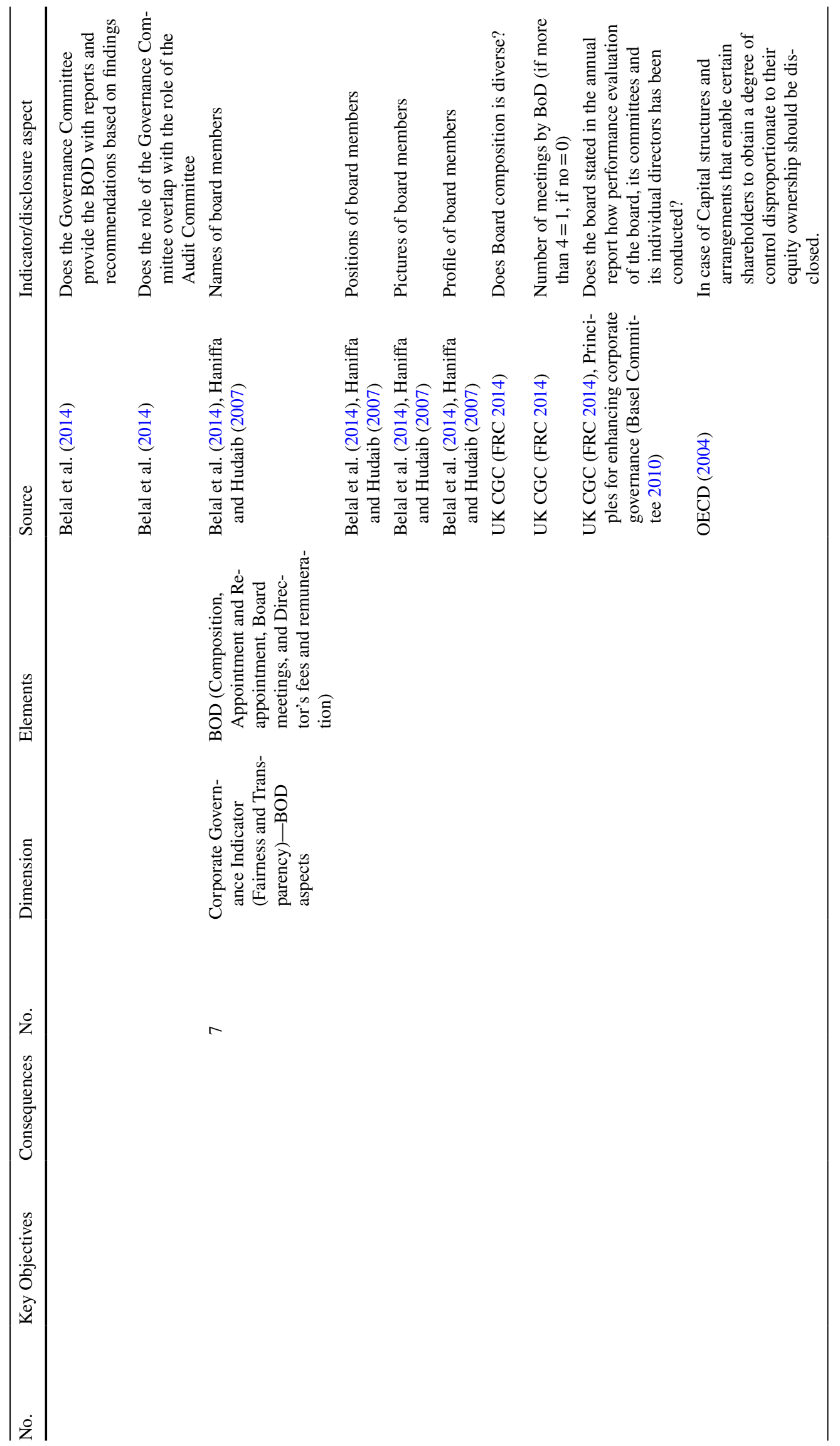




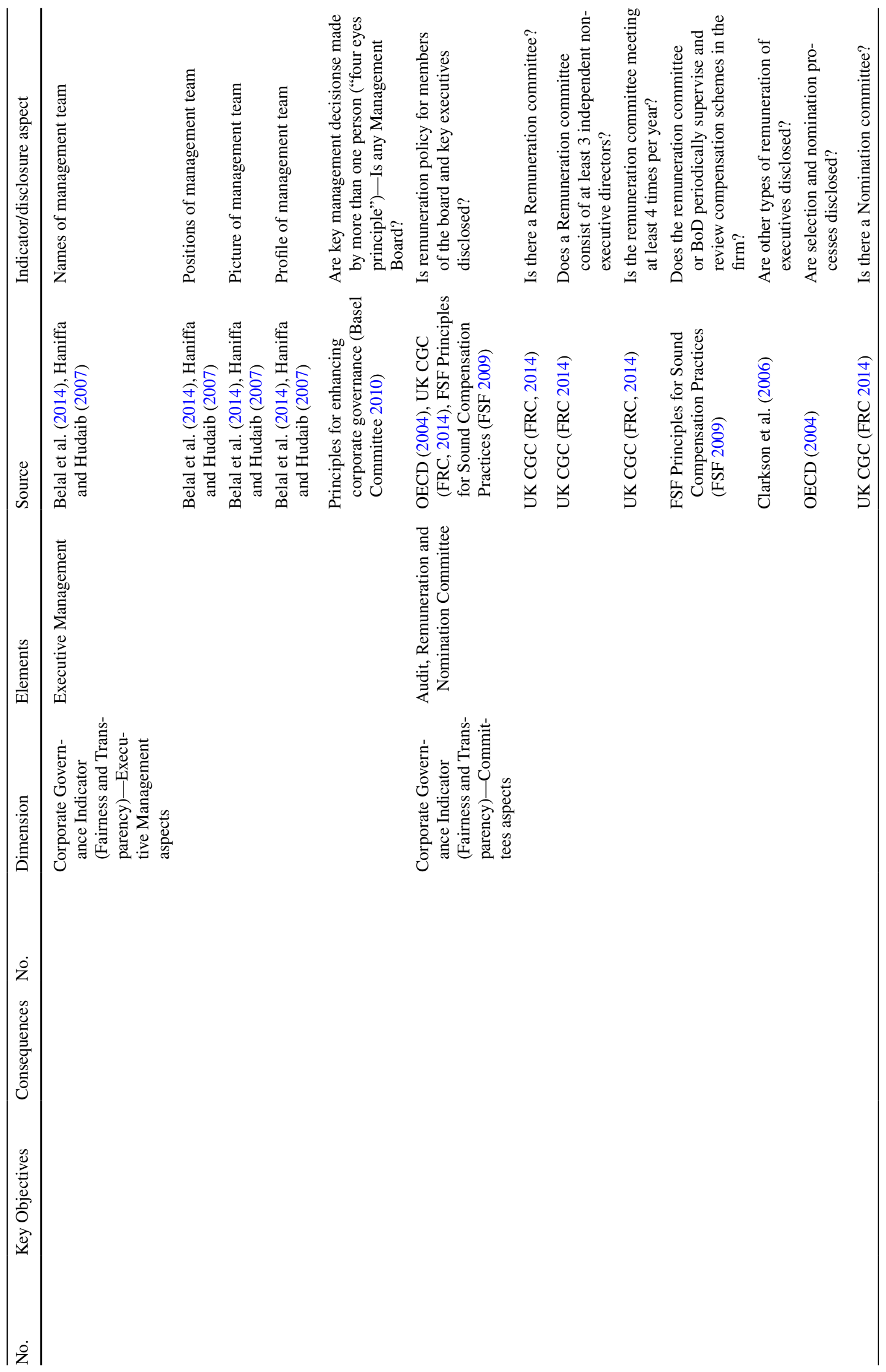




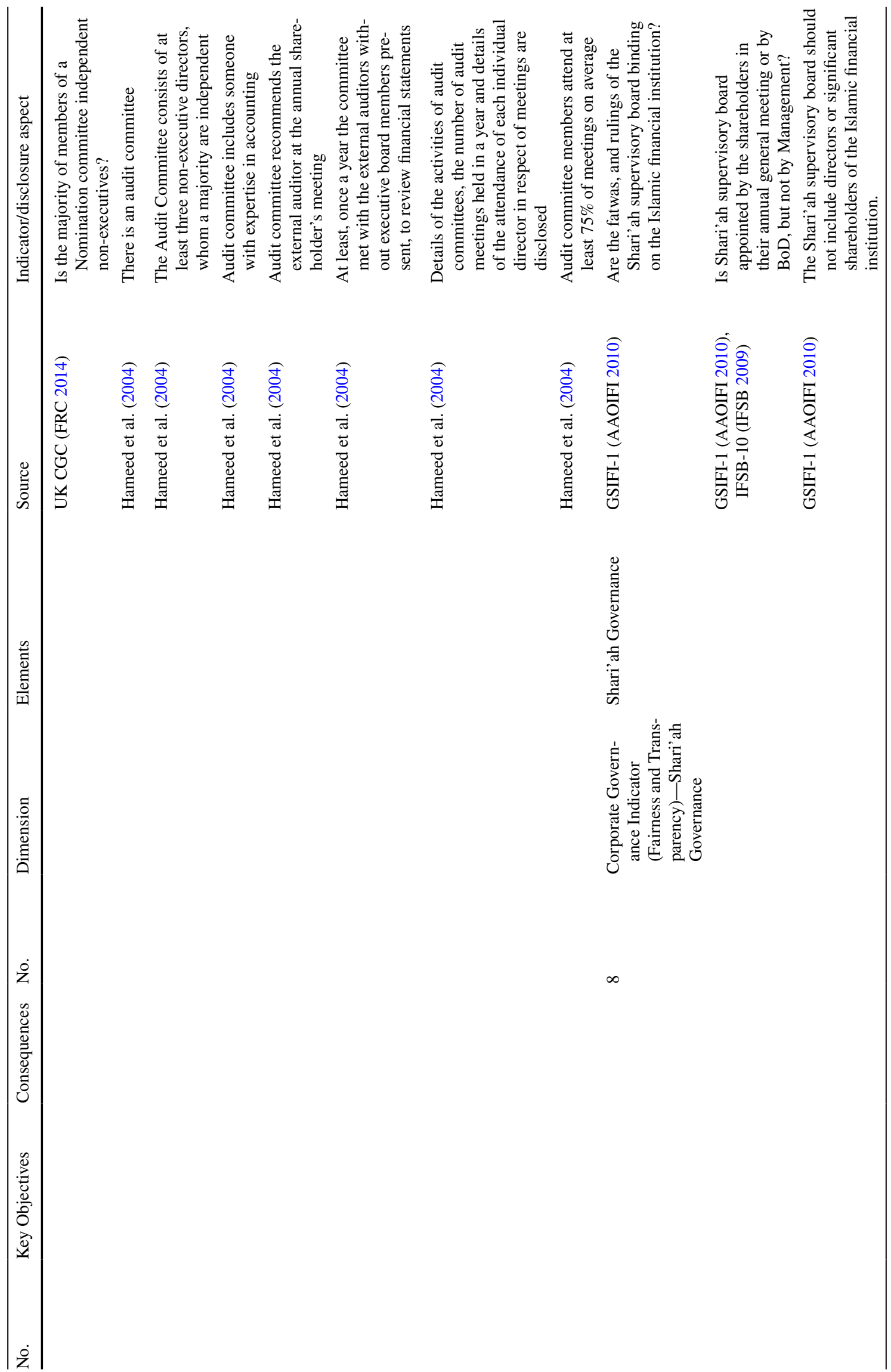




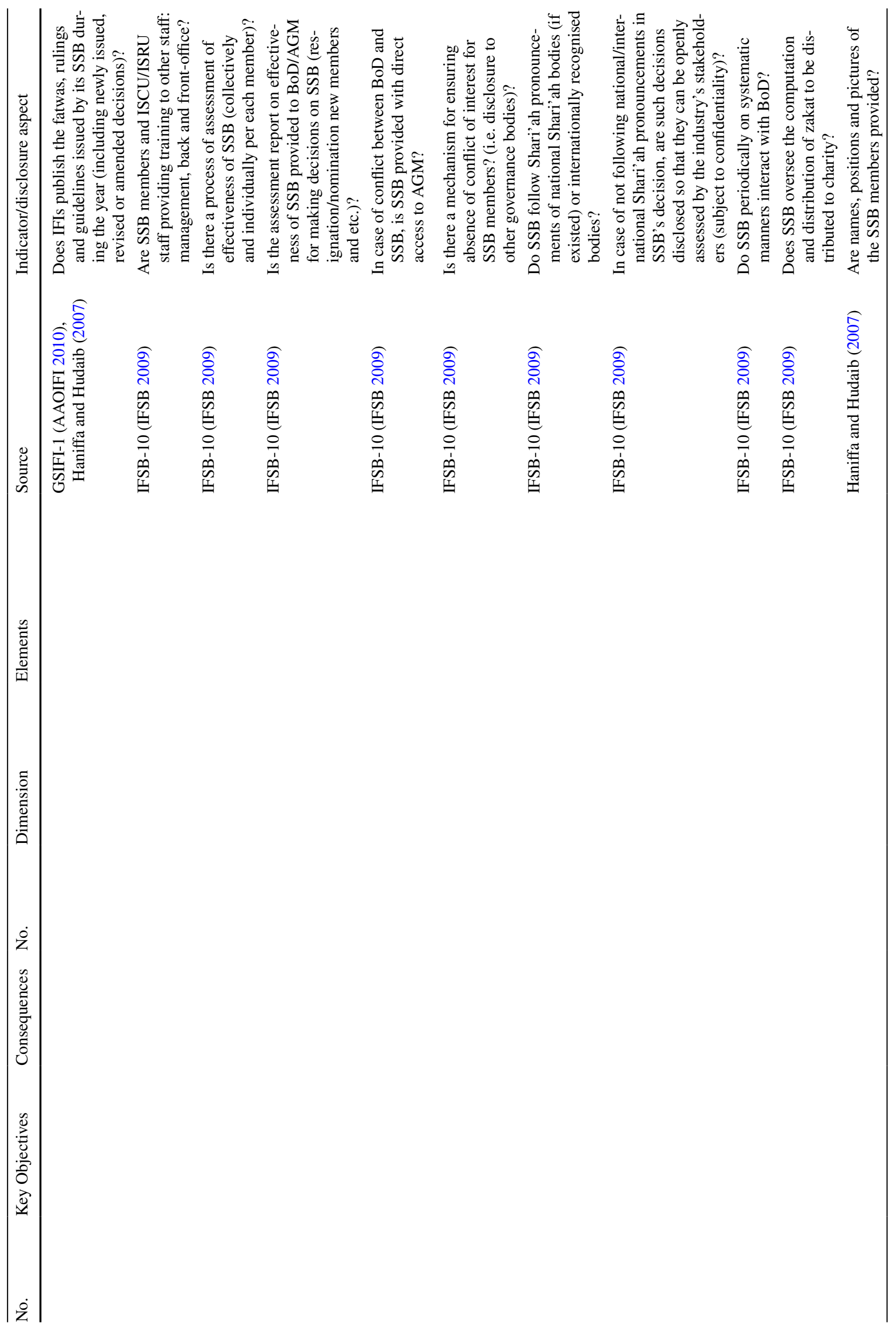




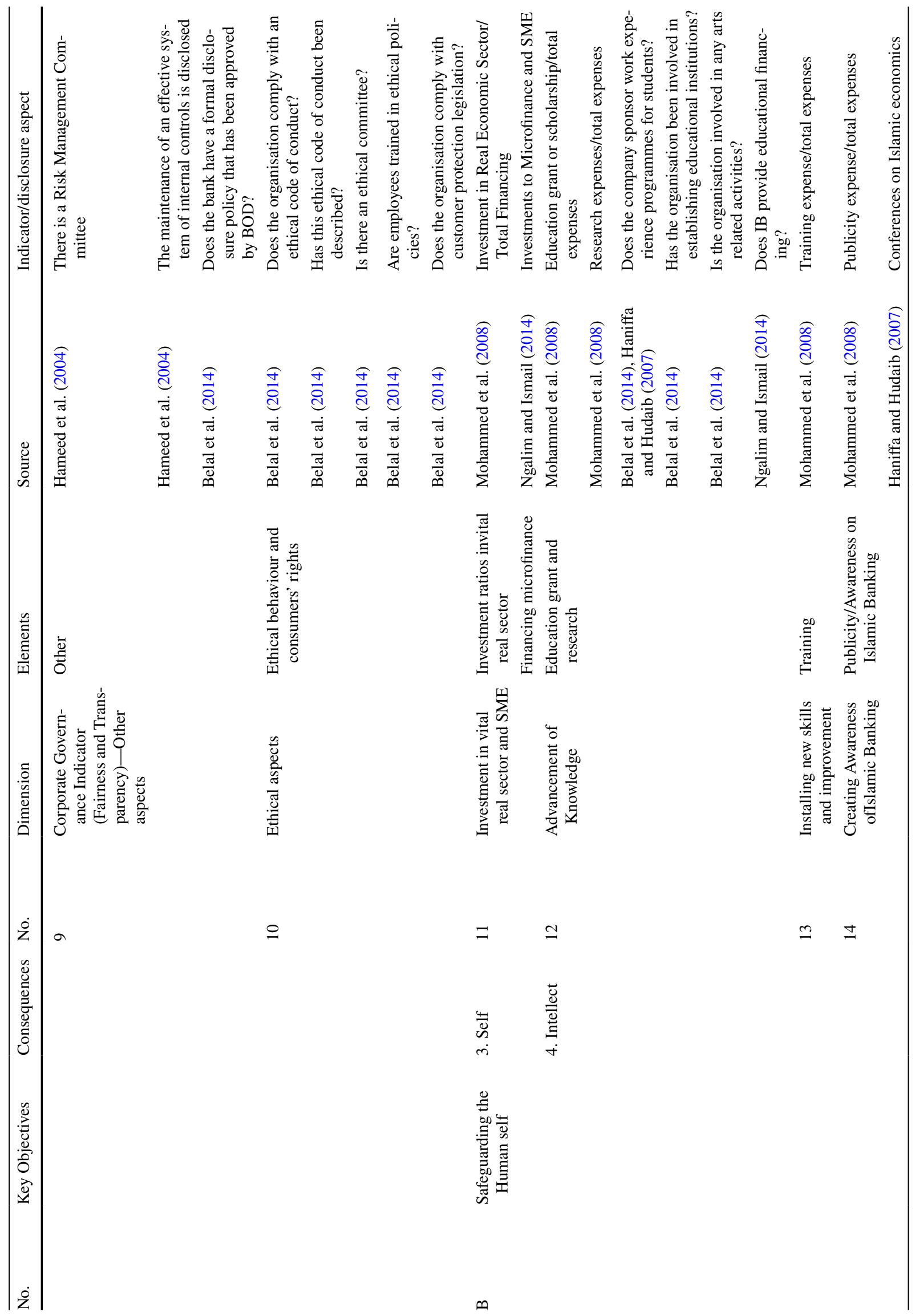




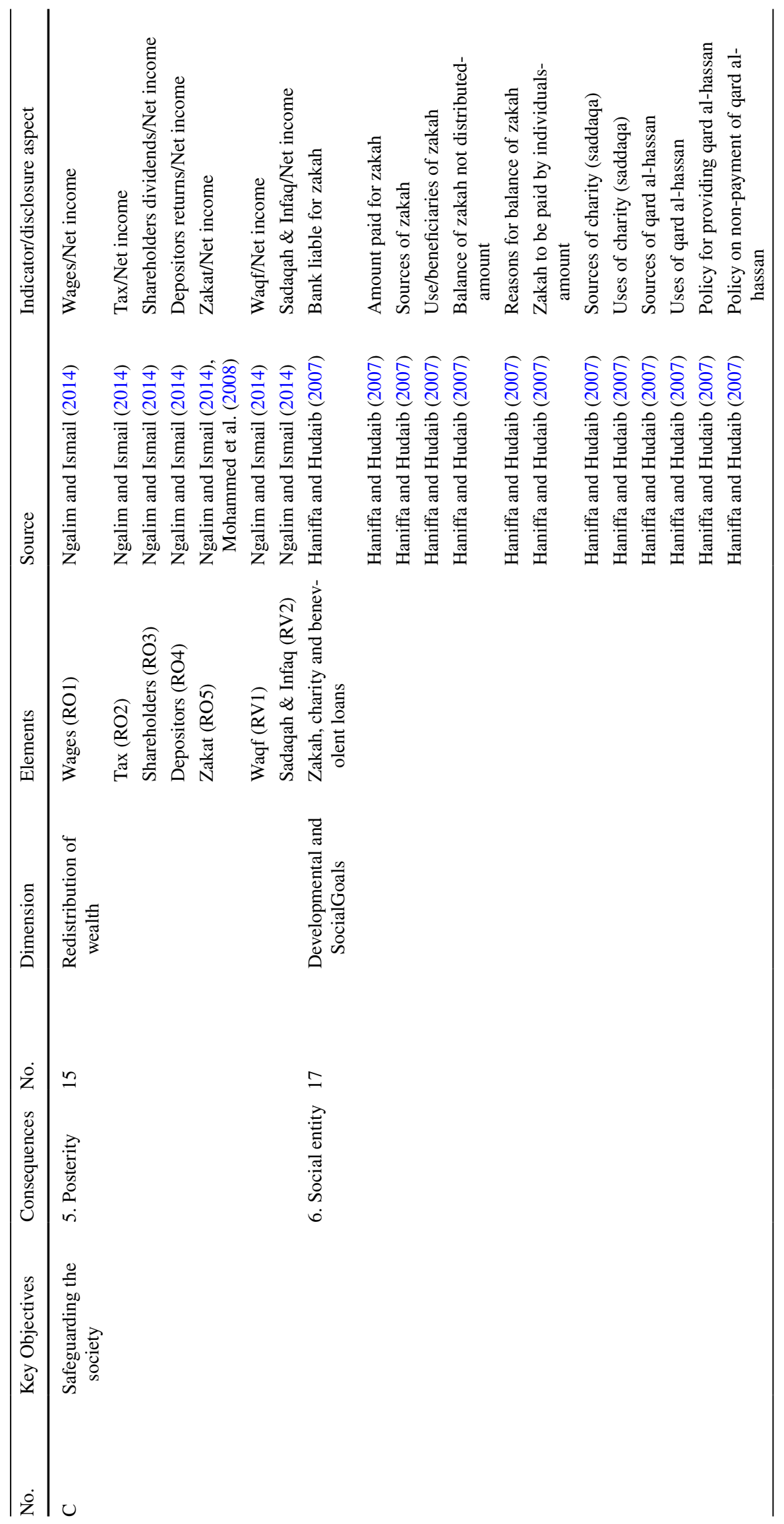




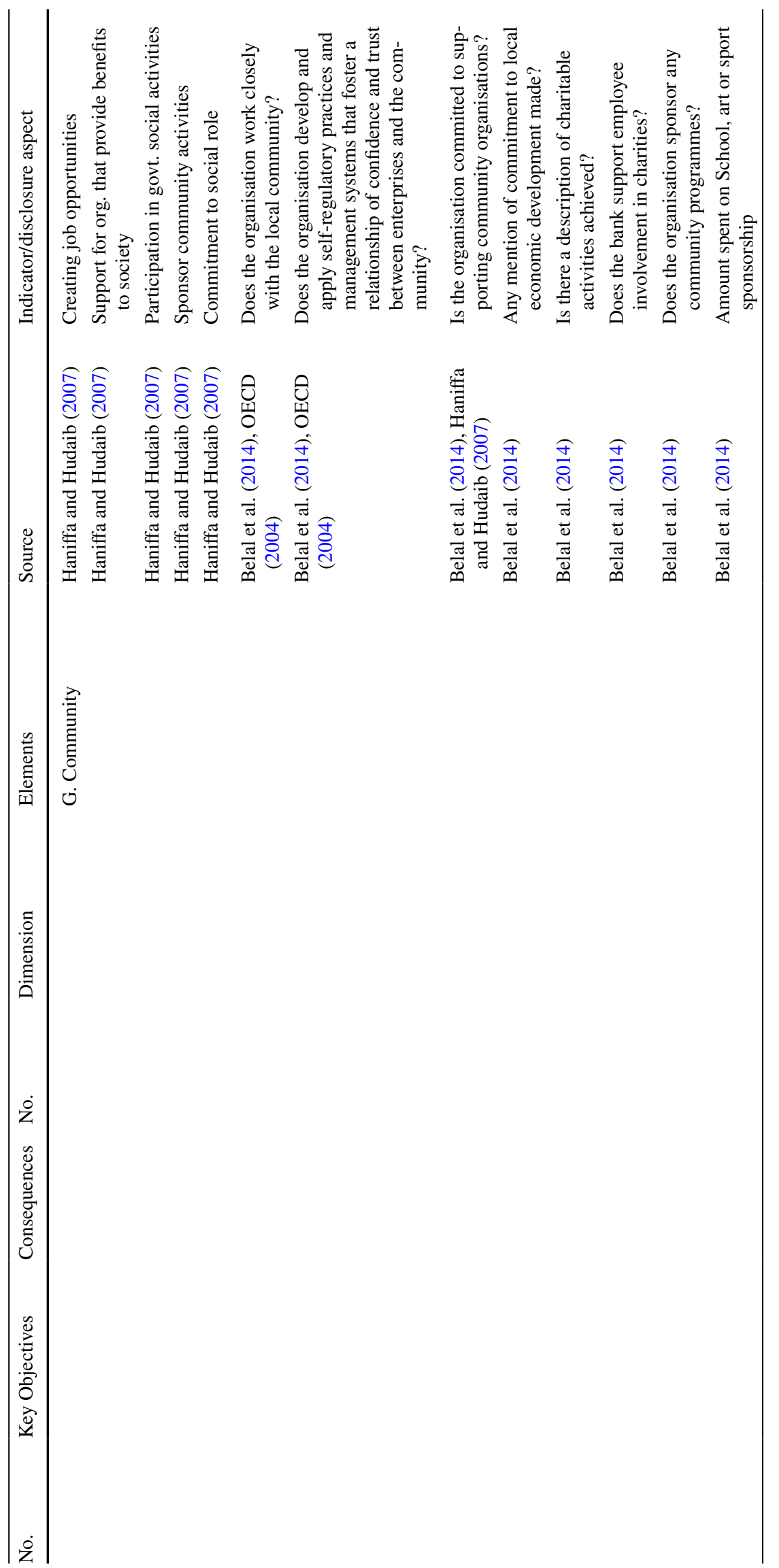




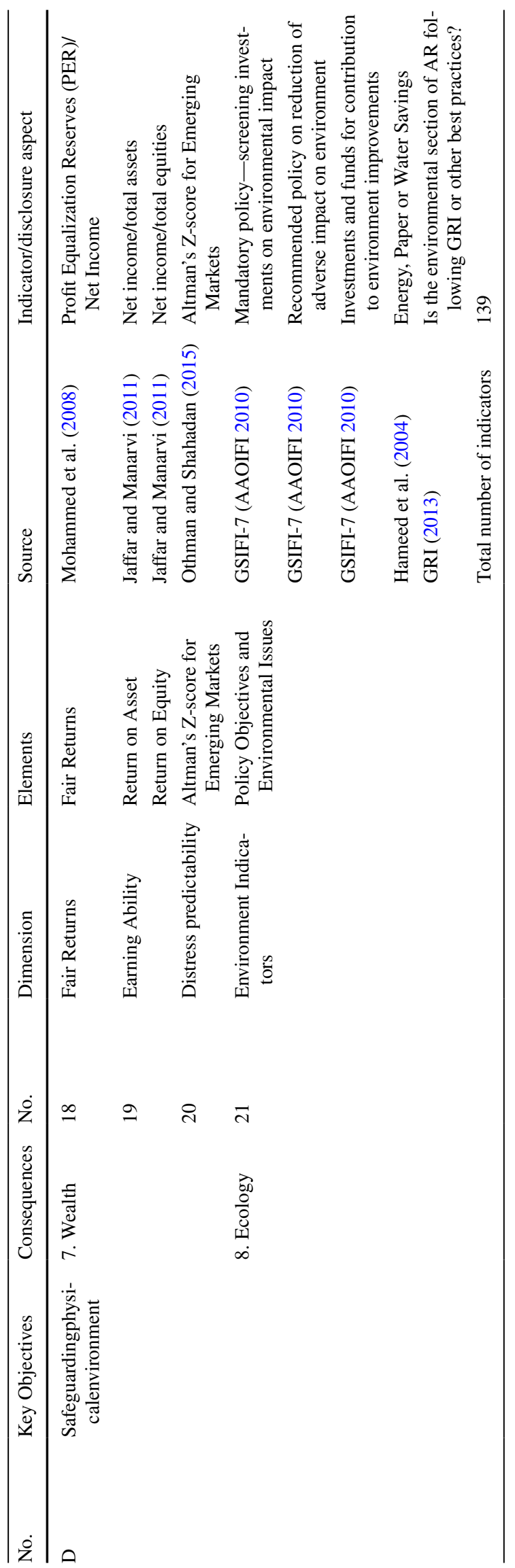




\section{References}

AAOIFI. (2010). Accounting, accounting and auditing organization for Islamic financial institutions. Manama: Auditing and Governance Standards for Islamic Financial Institutions.

Aggrawal, R. K., \& Yousef, T. (2000). Islamic banks and investment financing. Journal of Money, Credit and Banking, 32(1), 93-120.

Aguinis, H., \& Glavas, A. (2012). What we know and don't know about corporate social responsibility: A Review and Research agenda. Journal of Management, 38, 932-968.

Ahmed, H. (2011a). Product development in Islamic banks. Edinburgh: Edinburgh University Press.

Ahmed, H. (2011b). Maqasid al-Shari'ah and Islamic financial products: A framework for assessment. ISRA International Journal of Islamic Finance, 3(1), 149-160.

Ahmed, H. (2011c). Shari'ah governance regimes for Islamic finance: Types and appraisal. Economia Internazionale, 64(4), 393-412.

Aksak, E., \& Asutay, M. (2015). The Maqasid and the empirics: Has islamic finance fulfilled its promise? In M. Asutay \& A. Q. Turkistani (Eds.), Islamic finance: Political economy, values and innovation (pp. 187-219). Berlin: Gerlach Press.

Ali, A. J. (2009). Islamic perspectives on leadership: A Model. International Journal of Islamic and Middle Eastern Finance and Management, 2(2), 160-180.

Amir-Ud-Din, R. (2014). Maqasid al-Shari'ah: Are we measuring the Immeasurable? Islamic Economic Studies, 22(2), 1-32.

Antonio, M. S., Sanrego, Y. D., \& Taufiq, M. (2012). An analysis of Islamic banking performance: Maqashid index implementation in Indonesia and Jordan. Journal of Islamic Finance, 1(1), 12-29.

Asutay, M. (2007a). Conceptualisation of the Second best solution in overcoming the social failure of Islamic banking and finance: Examining the overpowering of homoislamicus by homoeconomicus. IIUM Journal of Economics and Management, 15(2), 167-195.

Asutay, M. (2007b). A political economy approach to Islamic economics: Systemic understanding for an alternative economic system. Kyoto Bulletin of Islamic Area Studies, Special Issue: Islamic Economics-Theoretical and Practical Perspectives in a Global Context, 1(2), 3-18.

Asutay, M. (2012). Conceptualising and locating the social failure of Islamic finance: Aspirations of Islamic Moral economy versus the realities of islamic finance. Journal of Asian and African Area Studies, 11(2), 93-113.

Asutay, M. (2013). Islamic moral economy as the foundation of Islamic finance. In V. Cattelan (Ed.), Islamic finance in Europe: Towards a plural financial system. Cheltenham: Edward Elgar.

Asutay, M. (2019). Islamic finance, ESGs and SDGs. i-Fikr Digest, 12(April), 4-7.

Asutay, M., \& Harningtyas, A. F. (2015). Developing Maqasid alShari'ah index to evaluate social performance of Islamic banks: A conceptual and empirical attempt. International Journal of Islamic Economics and Finance Studies, 1(1), 5-64.

Asutay, M., \& Yilmaz, I. (2018). Re-embedding Maqasid al-Shari'ah in the essential methodology of Islamic economics. In M. Mesawi (Ed.), Maqasid Al-Shari'ah: Explorations and Implications. Kuala Lumpur: Islamic Book Trust.

Auda, J. (2007). Maqasid al-Shariah as philosophy of Islamic law: A systems approach. London: International Institute of Islamic Thought.

Aydin, N. (2017). Islamic vs conventional human development index: Empirical evidence from ten Muslim countries. International Journal of Social Economics, 44(12), 1562-1583.

Ayub, M. (2007). Understanding Islamic finance. Chichester: Wiley.

Bank Negara Malaysia. (2016). Financial report and payment system. Kuala Lumpur: BNM.
Basel Committee. (2010). Principles for enhancing corporate governance. Basel: Bank for International Settlements Communications. Accessed August 3, 2015, from http://www.bis.org/publ/bcbs1 68.pdf.

Beck, T., Demirguc-Kunt, A., \& Merrouche, O. (2013). Islamic vs. conventional banking: Business model, efficiency, and stability. Journal of Banking \& Finance, 37, 433-447.

Bedoui, H. E. (2012). "Shari'a-based ethical performance measurement framework". Paris: CEFN, University of Sorbonne. Accessed June 14, 2015, from http://cenf.univ-paris1.fr/filea dmin/Chaire_CENF/Shari\%E2\%80\%98a-based_ethical_perfo rmancemeasurement_framework_Sorbonne_14th_January_Houss em_eddine_BEDOUI.pdf.

Bedoui, H. E., \& Mansour, W. (2014). Performance and Maqasid alShari'ah's pentagon-shaped ethical measurement. Science and Engineering Ethics, 21(3), 555-576.

Beekun, R. I. (2012). Character centered leadership: Muhammad (p) as an ethical role model for CEOs. Journal of Management Development, 31(10), 1003-1020.

Belal, A., Abdelsalam, O., \& Nizamee, S. (2014). Ethical reporting of Islami Bank Bangladesh (1983-2010). Journal of Business Ethics, 129(4), 769-784.

Biggeria, M., \& Mauro, V. (2018). Towards a more 'sustainable' human development index: Integrating the environment and freedom. Ecological Indicators, 91, 220-231.

Brooks, C. (2008). Introductory econometrics for finance. Cambridge: Cambridge University Press.

Chapra, M. U. (1985). Towards a just monetary system. Leicester: The Islamic Foundation.

Chapra, M. U. (2000). The future of economics: An Islamic perspective. Leicester: The Islamic Foundation.

Chapra, M. U. (2008). The Islamic vision of development in light of Maqasid al-Shari'ah. London: The International Institute of Islamic Thought.

Chapra, M. U., \& Ahmed, H. (2002). Corporate governance in Islamic financial institutions. Jeddah: Islamic Research and Training Institute (IRTI).

Choudhury, M. A., \& Hoque, M. Z. (2006). Corporate governance in Islamic perspective. Corporate Governance: The International Journal of Business in Society, 6(2), 116-128.

Clarkson, P., Van Bueren, A. L., \& Walker, J. (2006). Chief executive officer remuneration disclosure quality: Corporate responses to an evolving disclosure environment. Accounting and Finance, 46(5), 771-796.

Dar, H. A. (2004). On making human development more humane. International Journal of Social Economics, 31(11/12), 1071-1088.

Dusuki, A. W. (2008). What does Islam say about corporate social responsibility? Review of Islamic Economics, 12(1), 5-28.

El-Gamal, M. A. (2006). Islamic finance: Law, economics and practice. New York: Cambridge University Press.

Farook, S. M., Hassan, K., \& Lanis, R. (2011). Determinants of corporate social responsibility disclosure: The case of Islamic banks. Journal of Islamic Accounting and Business Research, 2(2), $114-141$

Farooq, M. O., \& Selim, M. (2018). Conceptualization of the real economy and Islamic finance: Transformation beyond the assetlink rhetoric. Thunderbird International Business Review, 61, 5. https://doi.org/10.1002/tie.22013.

Financial Reporting Council (FRC). (2014). The UK Corporate Governance Code. Accessed August 3, 2015, from https://www.frc. org.uk/Our-Work/Publications/Corporate-Governance/UK-Corpo rate-Governance-Code-2014.pdf.

Financial Stability Forum (FSF). (2009). FSF principles for sound compensation practices. Accessed August 3, 2015, from http:// www.financialstabilityboard.org/wp-content/uploads/r_0904b .pdf?page_moved=1. 
Gazdar, K., \& Grassa, R. (2015). What determines Islamic financial development? Empirical evidence from GCC countries. In M. Asutay \& A. Q. Turkistani (Eds.), Islamic finance: Risk, stability and growth (pp. 295-313). Berlin: Gerlach Press.

Global Reporting Initiatives (GRI). (2013). Sustainability reporting practices. Accessed August 3, 2015, from https://www.globalrepo rting.org/resourcelibrary/GRIG4-Part1-Reporting-Principles-andStandard-Disclosures.pdf.

Greene, W. H. (2003). Econometric analysis (5th ed.). Upper Saddle River, NJ: Prentice Hall.

Gujarati, D. N. (2003). Basic econometrics. New York: McGraw-Hill/ Irwin.

Hameed, S., Wirman, A., Alrazi, B., Nazli, M., \& Pramono, S. (2004). Alternative Disclosure \& Performance Measures for Islamic Banks. Kuala Lumpur: International Islamic University Malaysia. Accessed June 14, 2015, from http://faculty.kfupm.edu.sa/coe/ sadiq/proceedings/SCAC2004/50.ASC089.EN.Shahul.Alternativ e\%20Disclosure\%20\&\%20Performance\%20_1_.pdf.

Haniffa, R., \& Hudaib, M. (2007). Exploring the ethical identity of Islamic banks via communication in annual reports. Journal of Business Ethics, 76, 97-116.

Hasan, H., \& Ali, S. S. (2018). Measuring deprivation from Maqāṣid Al-Sharīah dimensions in OIC countries: Ranking and policy focus. Journal of King Abdulaziz University: Islamic Economics, 31(1), 3-26.

Hassan, Z. (2012). Shari'ah governance in Islamic banks. Edinburgh: Edinburgh University Press.

IFSB. (2009). IFSB-10: Guiding principles on Shari'ah governance systems for institutions offering only Islamic financial services. Kuala Lumpur: IFSB.

Iqbal, M., \& Molyneux, P. (2005). Thirty years of Islamic banking: History, performance and prospects. London: Palgrave-Macmillan.

Jaffar, M., \& Manarvi, I. (2011). Performance comparison of Islamic and Conventional banks in Pakistan. Global Journal of Management and Business Research, 11(1), 61-66.

Jones, M. T. (1999). The institutional determinants of social responsibility. Journal of Business Ethics, 72, 243-262.

Kasri, R., \& Ahmed, H. (2015). Assessing socio-economic development based on Maqāṣid al-Sharī‘ah principles: Normative frameworks, methods and implementation in Indonesia. Islamic Economics Journal, 21(3), 73-100.

Khan, F. (2010). How "Islamic" is Islamic banking? Journal of Economic Behaviour and Organization, 76, 805-820.

Kunapatarawong, R., \& Martinez-Ros, E. (2013). Influences of institutional pressures on corporate social responsibility attitude and corporate social responsibility outcomes. Working Paper 13-03. Business Economic Series of Universidad Carlos III de Madrid.

Mili, M. (2014). A structural model for human development: Does Maqasid al-Shari'ah Matter! Islamic Economic Studies, 22(2), 47-64.

Mirakhor, A., \& Zaidi, I. (2007). Profit-and-loss sharing contracts in Islamic finance. In M. K. Hassan \& M. K. Lewis (Eds.), Handbook of Islamic banking (pp. 49-63). Cheltenham: Edward Elgar.

Mirzaei, A. (2011). The effect of market power on stability and performance of Islamic and conventional banks. Islamic Economic Studies, 18(1/2), 45-81.

Mishra, S., \& Nathan, H. S. K. (2018). A manush or humans characterisation of the human development index. Journal of Human Development and Capabilities, 19(3), 398-415.

Mohamed, H. (2018). Macro and micro-level Indicators of Maqāșid alShar'̄ah in socio-economic development policy and its governing framework. Islamic Economic Studies, 25(3), 19-44.

Mohammed, M. O., Dzuljastri, A. R., \& Fauziah, M. T. (2008). The Performance measures of Islamic banking based on the Maqasid framework. Paper presented on IIUM International Accounting Conference (INTAC IV) held at Putra Jaya Marroitt, Malaysia.
Mollah, S., \& Zaman, M. (2015). Shari'ah supervision, corporate governance and performance: Conventional vs. Islamic banks. Journal of Banking \& Finance, 58, 418-435.

Moqbel, T. (2014). Evaluating the Shariah compliance and operationalising Maqasid Al Shariah: The case for Islamic project finance contracts. Unpublished Ph.D. Thesis, Durham Centre for Islamic Economics and Finance, Durham University Business School, UK.

Nagaoka, S. (2007). Beyond the theoretical dichotomy in Islamic finance: Analytical reflections on Murabahah contracts and Islamic debt securities. Kyoto Bulletin of Islamic Area Studies, 1(2), 72-91.

Nasr, S. H. (1978). The complementarity of contemplative and active lives in Islam. In Y. Ibish \& I. Marculescu (Eds.), Contemplation and action in world religions. Seattle: University of Washington Press.

Newson, M., \& Deegan, C. (2002). Global expectations and their association with corporate social disclosure practices in Australia, Singapore, and South Korea. The International Journal of Accounting, 37, 183-213.

Ngalim, S. M., \& Ismail, A. G. (2014). An Islamic vision development based indicators in analysing the Islamic banks performance: Evidence from Malaysia, Indonesia and selected GCC countries. IRTI Working Papers WP-1436-02. Jeddah: IRTI-Islamic Development Bank.

Ngalim, S. M., Ismail, A. G., \& Yaa'kub, N. I. (2015). A comparative analysis of the Maqasid Shari'ah of Islamic banks in Malaysia, Indonesia and the Gulf Cooperation Council Countries. In M. Asutay \& A. Q. Turkistani (Eds.), Islamic finance: Political economy, values and innovation (pp. 221-252). Berlin: Gerlach Press.

Ngoo, Y. T., \& Tey, N. P. (2019). Human development index as a predictor of life satisfaction. Journal of Population and Social Studies, 27(1), 70-86.

OECD. (2004). Principles of corporate governance. Accessed August 3, 2015, from http://www.oecd.org/corporate/ca/corporategovern anceprinciples/31557724.pdf.

Oikonomou, I., Brooks, C., \& Pavelin, S. (2012). The impact of corporate social performance on financial risk and utility: A longitudinal analysis. Financial Management, 41(2), 483-515.

Othman, J., \& Shahadan, M. A. (2015). Predicting banking distress in GCC countries using the emerging market z-score model: A comparative study. In M. Asutay \& A. Q. Turkistani (Eds.), Islamic finance: risk, stability and growth (pp. 115-140). Berlin: Gerlach Press.

Platonova, E. (2013). Corporate social responsibility from an Islamic moral economy perspective: A literature survey. Afro Eurasian Studies, 2(Issues 1\&2, Spring \& Fall), 272-297.

Rizkiningsih, P., \& Dewi, M. K. (2015). Factors influencing Islamic Social Reporting (ISR): An empirical study in Islamic banks in Indonesia, Malaysia and the GCC Countries. In M. Asutay \& A. Q. Turkistani (Eds.), Islamic finance: Performance and efficiency (pp. 287-308). Berlin: Gerlach Press.

Rudnyckyj, D. (2014). Economy in practice: Islamic finance and the problem of market reason. American Ethnologist, 41(1), 110-127.

Rudnyckyj, D. (2018). Beyond debt: Islamic experiments in global finance. New York: Chicago University Press.

Sairally, S. (2007). Community development financial institutions: Lessons in social banking for the Islamic financial industry. Kyoto Bulletin of Islamic Area Studies, 1(2), 19-37.

Sekaran, U. (2000). Research methods for business A skill business approach. New York: Wiley.

Shafii, Z., Abidin, A. Z., \& Salleh, S. (2015). Integrated Internal-External Shariah Audit Model: A proposal towards the enhancement of Shariah assurance practices in Islamic financial institutions. 
Working Papers No 1436-7. Jeddah: The Islamic Research and Teaching Institute (IRTI).

Shafii, Z., \& Salleh, S. (2010). Enhancing governance, accountability and transparency in Islamic financial institutions: An examination into the audit of Shari' a internal control system. Management \& Accounting Review (MAR), 9(2), 23-42.

Siddiqi, M. N. (2004). What went wrong? Keynote Address at the Roundtable on Islamic Economics: Current State of Knowledge and Development of Discipline held at Jeddah, Saudi Arabia, 26-27 May 2004 under joint auspices of the IRTI, Jeddah; and the Arab Planning Institute, Kuwait.

Suzuki, Y., \& Miah, M. D. (2015). Transcending the trend of financialization: The heterodox vs. Islamic economics view. Journal of Economic and Social Thought, 2(4), 226-241.

The Banker. (2017). Top Islamic Financial Institutions. London: Financial Times.

Toor, S. (2008). Merging spirituality and religion: Developing an Islamic leadership theory. IIUM Journal of Economics and Management, 16(1), 15-46.

Yilmaz, I. (2018). Essays in Islamic moral economy: Developmentalist promises, the delusion of financialisation and methodological dilemma. Unpublished Ph.D. Thesis, Durham Centre for Islamic Economics and Finance, Durham University Business School, UK.
Yousef, T. M. (2004). The Murabaha syndrome in Islamic finance: Laws, institutions and politics. In C. M. Henry \& R. Wilson (Eds.), The politics of Islamic finance (pp. 63-80). Edinburgh: Edinburg University Press.

Zadek, S., Evans, R., \& Pruzan, P. (2013). Building corporate accountability: Emerging practice in social and ethical accounting and auditing. London: Routledge.

Zeitoun, H. (2013). Corporate governance and corporate social performance: A meta-regression analysis. University of Greenwich. Accessed June 16, 2015, from http://www2.gre.ac.uk/_data/asset s/pdf_file/0004/824413/Hossam-Zeitoun-Corporate-Governance -and-Corporate-Social-Performance-A-Meta-Regression-Analy sis.pdf.

Zouari, S. B. S., \& Taktak, N. B. (2012). Ownership structure and financial performance in Islamic banks: Does bank ownership matter? Working Paper No. 713. The Economic Research Forum (ERF).

Publisher's Note Springer Nature remains neutral with regard to jurisdictional claims in published maps and institutional affiliations. 